\title{
Partial resistance to powdery mildew and leaf rust of wheat in Egyptian and CIMMYT genotypes
}

\author{
Ibrahim S. Draz ${ }^{1 *}$ (D) and Thanaa H. Abd El-Kreem ${ }^{2}$ \\ Address: \\ ${ }^{1}$ Wheat Disease Research Department, Plant Pathology Research Institute, Agricultural Research Center, 12619, Giza, Egypt. \\ ${ }^{2}$ Wheat Research Department, Field Crop Research Institute, Agricultural Research Center, 12619, Giza, Egypt \\ *Corresponding author: Ibrahim S. Draz, dr.ibrahim_draz@yahoo.com \\ Received: 07-01-2021; Accepted: 27-02-2021; Published: 02-03-2021 \\ 10.21608/EJAR.2021.56575.1070
}

\begin{abstract}
Powdery mildew caused by Blumeria graminis f. sp. tritici and leaf rust caused by Puccinia triticina are among the most important widespread diseases of wheat (Triticum spp.). Seedling and adult plant partial resistance were assessed for both diseases in 46 wheat genotypes, including 20 Egyptian cultivars and 26 CIMMYT genotypes, during two growing seasons (2018/19 and 2019/20) in Egypt. Four Egyptian cultivars (cvs), Misr-1, Misr-2, Misr-3, Giza-171 and eight CIMMYT genotypes, Jupateco-73-R, Pavon-F-76, Opata-85, Thew, Kiskadee-1, Chewink-1, Exchange, Quaiu-1 showed partial resistance to both diseases at the seedling stage. They recorded the longest incubation period (IP) and latent period (LP) for both diseases. Seven Egyptian cvs, Misr-1, Misr-2, Misr-3, Giza-168, Giza-171, Sids-13, Sids-14 and ten CIMMYT genotypes, Lee, Otane, Pavon-F76, Opata-85, Tatara, Janz, Gatcher, Kenya-Sunbird, Exchange, Quaiu-1 appear to have consistently effective adult plant partial resistance to both diseases. They exhibited the lowest values of average disease index (ADI), average coefficient of infection (ACI), AUDPC, $r$-AUDPC. Strong inverse correlations observed between each of IP, LP and ADI, ACI and $r$-AUDPC indicate that seedling partial resistance traits (IP, LP) contribute to curbing the process of epidemic development under field conditions. Strong correlations observed between each of ADI, ACI and $r$-AUDPC imply that wheat breeders and pathologists may be able to assess their lines by a single scoring at an appropriate time. Cultivars with seedling and adult plant partial resistance may be of value in breeding for durable resistance to powdery mildew and leaf rust under Egyptian field conditions. Keywords: Wheat, Powdery mildew, Leaf rust, Partial resistance, Correlation Coefficient
\end{abstract}

\section{INTRODUCTION}

Powdery mildew caused by Bulmeria graminis f. sp. tritici (Bgt) and leaf rust caused by Puccinia triticina Eriks. (Pt) are among the most important widespread foliar diseases causing considerable losses in grain yield of common wheat (Triticum aestivum L.) and durum wheat (Triticum turgidum var. durum) worldwide (Huerta-Espino et al., 2011). Powdery mildew can cause loss in grain yield ranges from $13-34 \%$ when infection is low to moderate but under severe infection, loss may reach $50 \%$ (Leath and Bowen, 1989, Griffey et al., 1993; Li et al., 2011; Draz et al., 2019). Leaf rust is capable of causing 35-50\% yield loss (Abdel-Hak et al., 1980; Germán et al., 2007; Draz et al., 2015), while it could reach 60\% in endemic areas (Lesovoi et al., 1981). Both pathogens are spread all over the world in cold or warm and humid climates (Hua et al. 2009; Huerta-Espino et al. 2011). B. graminis f. sp. tritici attacks all parts of wheat plant; leaves, stems and heads, while $P$. triticina infects the leaf blades, it can also infect the leaf sheath and glumes in highly susceptible cultivars (Huerta-Espino et al., 2011). Significance of both pathogens, in particular, depends upon the prevalence of aggressive and/or virulent races of the pathogen as well as their affinity or compatibility with the genetic constitutions of the host in a given environment. The Egyptian wheat cultivars have suffered from sudden epidemics during the last decades from the perspective of change in weather conditions concerning the genetic makeup of both host and pathogen, causing up to $50 \%$ yield loss due to leaf rust and $26.68 \%$ due to powdery mildew (El-Daoudi et al., 1987; Draz et al., 2015, 2019). However, genetic resistance is the most important mean of controlling diseases. Race-specific resistance genes, following the gene-for-gene relationship, have been used extensively in breeding, but only one mutation is generally needed for a pathogen to change from avirulence to virulence (Yu et al., 2001; Kolmer et al., 2007). Thus, race-specific resistance is readily overcome by matching virulent pathotypes when varieties containing these resistances are used on a large scale for a sufficient length of time. To prolong the effectiveness of specific resistance, several methods, such as pyramiding, i.e. combining several resistance genes into a variety, multi-lines and cultivar mixtures (Vanderplank 1968, Browning and Frey 1969; Wolfe 1985; Herrera-Foessel et al., 2006; Kolmer et al., 2007) have been used. Another type of resistance, partial resistance, is characterized by a compatible interaction in all growth stages, but a lower infection frequency, a longer latent period, or a lower rate or a shorter period of spore production (Parlevliet 1975; Parlevliet and van Ommeren 1975, Kranz 1983). Partial resistance has provided durable control of powdery mildew and leaf rust in wheat (Shaner 1973; Das et al. 1993; Pandey et al., 1989). Since the early 1980s, through the efforts of breeders and pathologists, several resistant varieties have been released, intentionally or otherwise, for commercial production in Egypt (Nazim et al. 1983). However, these cultivars became susceptible to powdery mildew and/or leaf rust when they were grown over a large area after 4 or 5 years in Egypt (Nazim et al., 1983; Ashmawy et al., 2014; El-Shamy et al., 2016; Draz et al., 2015, 2019) as in other countries (Bennett 1984; Li et al., 2011; Asad et al., 2014). Egypt is located in the epidemiological zone of leaf rust (Saari and Prescott 1985) which eliminated many wheat cultivars such as Giza-139, Chenab-70, SuperX, Giza158 and Giza-160 (Nazim et al., 1983). Egypt has a vast cultivated area of wheat and many diverse varieties, but little attention 
has been paid so far to investigate the durability of resistance to powdery mildew and leaf rust. The objective of this study was to assess partial resistance to powdery mildew and leaf rust at seedling and adult plant stages in a collection of spring wheat cultivars widely grown in Egypt and selected wheat genotypes introduced from CIMMYT.

\section{MATERIAL AND METHODS}

Plant material:

In total, 46 wheat genotypes (Table 1), including 20 Egyptian wheat cultivars provided by the Wheat Research Department, Field Crop Research Institute, ARC, Egypt, and 26 wheat genotypes introduced from CIMMYT (TID: 926698, OCC: 1, Trial Name: CWGR19EGY013, Trial Abbr.: EGY-SH19090, Cycle: EGY2019, Program: BW) were investigated for partial resistance to powdery mildew and leaf rust during 2018/19 and 2019/20 growing seasons in Egypt. The universal wheat genotypes, Chancellor (powdery mildew) and Morocco (leaf rust) were used as susceptible checks.

Table 1. List of wheat genotypes and their pedigree tested for partial resistance to powdery mildew and leaf rust in Egypt.

\begin{tabular}{|c|c|c|}
\hline Entry & Genotype & Pedigree and selection history \\
\hline \multirow{20}{*}{ 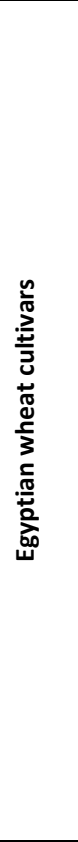 } & Misr-1 & Oasis/Skauz//4*BCN/3/2*PASTOR. CMSSOYO1881T-050M-030Y-O3OM-030WGY-33M-0Y-0S \\
\hline & Misr-2 & Skauz/Bav92. $\quad$ CMSS96M0361S-1M-010SY-010M-010SY-8M-0Y-0S \\
\hline & Misr-3 & Rolf-07*2/Kiritati $\quad$ CGSS 05 B00123T-099T-0PY-099M-099NJ-6WGY-0B-0BGY-0GZ \\
\hline & Sakha-93 & $\begin{array}{ll}\text { Sakha92/TR810328 } & \text { S8871-1S-2S-1S-0S } \\
\end{array}$ \\
\hline & Sakha-94 & Opata/Rayon//Kauz CMBW9043180-OTOPM-3Y-010M-010M-010Y-10M-015Y-0Y-0AP-0S \\
\hline & Sakha-95 & $\begin{array}{l}\text { PASTOR//SITE/MO/3/CHEN/AEGILOPSSQARROSA(TAUS)//BCN/4/WBLL1 } \\
\text { CMA01Y00158S-040POY-040M-030ZTM-040SY-26M-0Y-0SY-0S }\end{array}$ \\
\hline & Giza-168 & MIRLO(MRL)/BUCKBUCK//SERI-82 $\quad$ CM93046-8M-OY-OM-2Y-OB \\
\hline & Giza-171 & $\begin{array}{ll}\text { Sakha93/Gemmeiza9 S.6-1GZ-4GZ-1GZ-2GZ-0S } \\
\end{array}$ \\
\hline & Gemmeiza-9 & ALD"S"/HUAC"S"//CMH74A.630/SX. GM4583-5GM-1GM-0GM \\
\hline & Gemmeiza-10 & Maya74"S"/on/1160-147/3/Bb/G11/4/chat"S"/5/crow $\quad$ "S"CG5820-3G-1G-2G-0G \\
\hline & Gemmeiza-11 & BOW "S"/KVZ "S"//7C/Seri82/3/Giza168/Sakha61 CGM7892-2GM-1GM-2GM-1GM0GM \\
\hline & Gemmeiza-12 & \multirow{2}{*}{$\begin{array}{l}\text { OTUS/3/SARA/THB//VEE CMSS97Y00227S-5Y-010M-010Y-010M-2Y-1M-0Y-0GM } \\
\text { BUC//7C/ALD/5/MAYA74/ON//1160-147/3/BB/GLL/4/CHAT"S"/6/MAYA/VUL//CMH74A.630/4*SX } \\
\text { SD70964SD-1SD-1SD-0SD }\end{array}$} \\
\hline & Sids-12 & \\
\hline & Sids-13 & KAUZ "S"//TSI/SNB "S".ICW94-0375-4AP-2AP-030AP-0APS-3AP-0APS-050AP-0AP-0SD \\
\hline & Sids-14 & SW8488*2/KUKUNA $\quad$ CGSS01Y00081T-099M-099Y-099M-099B-9Y-0B-0SD \\
\hline & Shandweel-1 & SITE//MO/4/NAC/TH.AC//3*PVN/3/MIRLO/BUC. $\quad$ CMSS93B00567S-72Y-010M-010Y-010M-0HTY \\
\hline & Beniswef-1 & JORI-69(SIB)/(SIB)ANHINGA//(SIB)FLAMINGO.MEX CM-9799 \\
\hline & Beniswef-3 & CD-48693-10Y-1M-1Y-0M \\
\hline & Beniswef-4 & AUSL/5/CANDO/4/BY*2/TACE//II27655/3/TME//ZB/W*2. ICD88-1120-ABL-0TR-1BR-0TR-6AP-OSD \\
\hline & Sohag-3 & MIEX" S" /M G HA /51792//D URUM6 \\
\hline \multirow{26}{*}{ 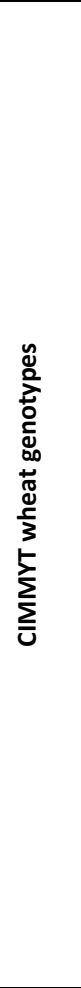 } & Clement & HOPE/TIMSTEIN//3*HEINES-VII/3/RIEBESEL-57-41/2*HEINES-VII/4/CLEO \\
\hline & Heines-Peko & PERAGIS/HEINES-KOLBEN \\
\hline & Lee & HOPE//BOBIN*2/GAZA \\
\hline & Otane & TOBARI-66(SIB)/NAPO-63//NOROESTE-66/ERA/3/BLUEBIRD/GALLO \\
\hline & Jupateco-73-R & II-12300//LERMA-ROJO-64/II-8156/3/NORTENO-67 \\
\hline & Jupateco-73-S & II-12300//LERMA-ROJO-64/II-8156/3/NORTENO-67 \\
\hline & Pavon-F-76 & VICAM-71//CIANO-67/SIETE-CERROS-66/3/KALYANSONA/BLUEBIRD \\
\hline & Opata-85 & BLUEJAY(SIB)/JUPATECO-73 \\
\hline & Super-Kauz & JUPATECO-73/BLUEJAY//URES-81 \\
\hline & Tatara & JUPATECO-73(SIB)ALONDRA//(SIB)KINGLET \\
\hline & Janz & 3-AG-3/4*CONDOR//COOK \\
\hline & Gatcher & CHARTER/3*GABO/3/SANTA-CATALINA/THATCHER//MAYO-54 \\
\hline & Trident & VPM-1/5*COOK//4*SPEAR \\
\hline & Hussar & SQUADRON/RENDEZVOUS \\
\hline & Manitou & RL-4125//THATCHER*6/PI-170925 \\
\hline & Kenya-Sunbird & ND-643/2*WEEBILL-1 \\
\hline & Amigo & OK-66-C-3190/6/GAUCHO(M)/4/TASCOSA/3/WICHITA//WICHITA(M)/TEEWON/5/2*TEEWON \\
\hline & Thew & BLOUNTS-LAMBRIGG//FIFE/SINEW/3/FIFE/HUSSAR,AUS \\
\hline & Kiskadee-1 & WHEATEAR/KUKUNA//WHEATEAR \\
\hline & Chewink-1 & WHEATEAR/TUKURU//WHEATEAR \\
\hline & Transec & (M)SELECTION-82-AL-2-4-7/CHINESE-SPRING \\
\hline & Grackle-1 & WAXWING*2/KUKUNA \\
\hline & Becard-1 & WEEBILL-1*2/KIRITATI \\
\hline & Eagle & TCL-UNIVERSITY_OF_MANITOBA/TCL-BULK \\
\hline & Exchange & WARDEN,AUS/HYBRID-ENGLISH \\
\hline & Quaiu-1 & BABAX/Lr42//BABAX*2/VIVITSI \\
\hline
\end{tabular}


Seedling evaluation for partial resistance:

At the seedling stage, the wheat genotypes (Table 1) were tested for partial resistance to powdery mildew and leaf rust under greenhouse conditions at El-Sabahia Agricultural Research Station, Alexandria. The experiment was carried out in a completely randomized design with three replicates. Seeds of the tested wheat genotypes were sown in plastic pots $(10 \mathrm{~cm}$. diam.) filled with clay soil and received 10 seeds per pot. Eight-day-old seedlings were separately inoculated with conidiospores of $B$. graminis f. sp. tritici (Bgt) and urediniospores of $P$. triticina (Pt) according to the inoculation methods described by Browder (1972) for powdery mildew and Roelfs et al. (1992) for leaf rust. The pathogen inocula involved the five Bgt (Bgt1-Bgt5 on virulence to Pm3, Pm8, Pm17) and twelve Pt pathotypes (CCBLG, FKTTT, KKTST, LKCFG, MHNLQ, MTTSN, PFKSS, PGSRP, PKPRT, PKSBB, PRSTT, TTTMS) prevalent in Egypt identified in our previous study (Draz et al., 2021). Artificial inoculation for each disease was performed separately, in which, each experiment for each disease was carried out in a separate chamber in the greenhouse. The inoculated plants were incubated in a dark dew chamber overnight at $18^{\circ} \mathrm{C}$, then moved to the benches in the greenhouse and maintained at $19-22^{\circ} \mathrm{C}$ and $95-100 \%$ relative humidity. Light intensity was supplied at about 7600 lux in a photoperiod of $16 \mathrm{~h}$ light and $8 \mathrm{~h}$ dark (Ohm and Shaner 1976). Seedlings were kept under observation until the development of rust pustules.

The seedling response was scored two weeks after inoculation based on the infection types expressed on each entry. The 0-4 classification standards of Shi et al. (1987) and Roelfs et al. (1992) were used to assess powdery mildew and leaf rust, respectively. Plants with infection types (ITs) 0-2 were considered resistant response (R) and their corresponding isolates are defined as avirulent, while ITs 3 and 4 were considered susceptible ones $(S)$ and their corresponding isolates as virulent. Partial resistance traits of the tested cultivars were estimated using two parameters i.e., incubation period (IP) and latent period (LP) according to Parlevliet (1975). The incubation period was measured by calculating the period (day) between inoculation and the appearance of a visible reaction on the plant. The latent period was measured by counting the number of visible pustules on marked leaves daily until no more pustules appeared. The time between inoculation and $50 \%$ visibility of the pustule was estimated as LP.

\section{Adult plant evaluation for partial resistance:}

At adult stage, the twenty Egyptian cultivars and twenty-six CIMMYT genotypes (Table 1) were screened in two field trials for partial resistance to powdery mildew and leaf rust during 2018/19 and 2019/20 growing

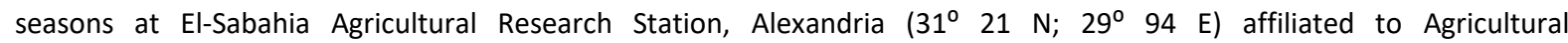
Research Center (ARC), Egypt. Cultivars were grown in three-row plots, each $1.5 \mathrm{~m}$ long with $30 \mathrm{~cm}$ between rows. The plots were arranged in a randomized block design with three replicates. Highly susceptible genotypes for powdery mildew (Chancellor) and leaf rust (Morocco) were grown $1.5 \mathrm{~m}^{2}$ belt around the plots as spreader plants. All recommended agricultural practices for wheat crop in the commercial fields were applied. When flag leaf just visible at GS 37 (Zadoks et al., 1974). The spreader plants of each experiment were inoculated with a mixture of isolates mentioned above of Bgt and Pt prevalent in Egypt. Conidiospores of Bgt was propagated on cv Chancellor as described above (Browder 1972). The propagated conidia were gently removed from the propagation of wheat plants and then dispersed over the spreader plants with a fine brush (van Silfhout and Gerechter-Amitai 1989). The inoculation with urediniospores of Pt was applied according to the method described by Tervet and Cassell (1951).

Mildew severity was assessed four times between GS45 and GS75, with 10 days intervals (Zadoks et al., 1974) using the 0-9 scale as described by Saari and Prescott (1975). Final mildew severity was expressed as disease index (DI) according to Sharma and Duveiller (2007). Host response to powdery mildew were categorized based on the disease index, in which, $1-10 \%=$ Resistance $(\mathrm{R}), 11-30 \%=$ Moderately Resistance (MR), $31-50 \%=$ Moderately Susceptible (MS), $51-60 \%=$ Susceptible (S), $61 \%$ and above = Highly Susceptible (HS). Rust severity and host response were assessed four times between GS 51 and GS 83, at 10 days intervals (Zadoks et al., 1974). Host responses to leaf rust, Resistant (R), Moderately Resistant (MR), Moderately Susceptible (MS) or Susceptible (S) were scored according to Roelfs et al. (1992). Rust severity was assessed following the modified Cobb's scale (Peterson et al., 1948). Final rust severity was expressed as disease index according to Das et al. (1993). Partial resistance was quantified in three ways. Coefficient of infection (Cl) according to Saari and Wilcoxson (1974) and Pathan and Park (2006) was calculated by multiplying the severity value by a constant value of $0.2,0.4,0.6,0.8$ and 1.0 for host response ratings of $R, M R, M R-M S, M S$ and $S$, respectively. The average coefficient of infection $(\mathrm{ACl})$ was calculated as mean $\mathrm{Cl}$ values over years. The area under disease progress curve (AUDPC) was calculated following Shaner and Finney (1977) for powdery mildew and Pandey et al. (1989) for leaf rust. The relative area under disease progress curve (r-AUDPC) was calculated by dividing the AUDPC value of the tested cultivar by the AUDPC value of the check susceptible genotype (Mutari et al., 2018) using the following equation:

$$
r-A U D P C=\frac{\text { AUDPC of cultivar }}{\text { AUDPC of susceptible check }} \times 100
$$




\section{The relationship among partial resistance traits:}

The relationship among partial resistance traits of the wheat cultivars at seedling and adult plant stages was determined by the correlation coefficient ( $r$ ) according to Pearson and Hartley (1970).

\section{Statistical analysis:}

Data were pooled from the repeated tested and subjected to analysis of variance using SPSS statistics computer program. Means were compared using LSD method at 0.05 significance (Steel and Torrie, 1980).

\section{RESULTS}

\section{Seedling partial resistance:}

Partial resistance assessment to powdery mildew and leaf rust in wheat seedlings indicated the presence of varied values in traits within the tested 46 genotypes (Table 2). The partial resistance at the seedling stage is characterized by a long incubation period (IP) as well as a long latent period (LP). Based on IP and LP data, the tested wheat cultivars were classified into their groups according to the components of partial resistance.

For powdery mildew, the IP ranged between 6 and 9 days (d), while the LP ranged between 8 and 12 days (d). Only four genotypes recorded the longest IP (9 days) and LP (12 days), including, two Egyptian cultivars (Misr-2, Giza-171) and two CIMMYT genotypes (Opata-85, Thew). Twelve cultivars came second (IP 9 d, LP 11 d), including three Egyptian cultivars (Misr-1, Misr-3, Gemmeiza-12) and nine CIMMYT cultivars (Lee, Jupateco-73-R, Pavon-F-76, Gatcher, Hussar, Kiskadee-1, Chewink-1 Exchange, Quaiu-1).

For leaf rust, the IP ranged between 6 and $9 \mathrm{~d}$, while the LP ranged between 8 and $13 \mathrm{~d}$. Nine genotypes recorded the longest IP (9 d) and LP (13 d), including, two Egyptian cultivars (Misr-2, Sids-14) and seven CIMMYT genotypes (Otane, Jupateco-73-R, Pavon-F-76, Opata-85, Janz, Thew, Kiskadee-1). Ten cultivars came second (IP 9 d, LP 12 d), including four Egyptian cultivars (Misr-1, Misr-3, Giza-171, Sids-13) and six CIMMYT cultivars (Lee, Super-Kauz, Kenya-Sunbird, Chewink-1, Exchange, Quaiu-1), followed by three Egyptian cultivars, Sakha-94, Giza-168, Shandweel-1 and CIMMYT cultivar Hussar exhibiting IP 9 d and LP $11 \mathrm{~d}$.

It is worth to notice that four Egyptian cultivars (Misr-1, Misr-2, Misr-3, Giza-171) and eight CIMMYT cultivars (Jupateco-73-R, Pavon-F-76, Opata-85, Thew, Kiskadee-1, Chewink-1, Exchange, Quaiu-1) displayed the longest IP and LP for both diseases. The remaining cultivars exhibited short IP (6-8 d) and LP (8-10 d) for each of powdery mildew and leaf rust. The susceptible check genotypes, Chancellor (powdery mildew) and Morocco (leaf rust) recorded the shortest IP and LP with $6 \mathrm{~d}$ and $8 \mathrm{~d}$, respectively.

\section{Adult plant partial resistance:}

Disease index (DI) for powdery mildew and coefficient of infection (CI) for leaf rust were assessed in the tested 46 wheat genotypes at adult plant stage during 2018/19 and 2019/20 growing seasons (Table 3). Analysis of variance of $\mathrm{DI}$ and $\mathrm{Cl}$ indicated highly significant differences between the performances of different genotypes. Data showed varied values of $\mathrm{DI}$ and $\mathrm{Cl}$ among genotypes ranged from 12.34 to $77.77 \mathrm{DI}$ and 2.00 to $70.00 \mathrm{Cl}$. Based on $\mathrm{DI}$ and $\mathrm{Cl}$ data, cultivars were classified into four categories, $0-20,>20-40,>40-60$ and $>60$.

For powdery mildew, the first category consisted of fifteen genotypes which recorded the lowest DI up to 20 during both years, including six Egyptian cultivars (Misr-1, Misr-2, Misr-3, Giza-168, Giza-171, Gemmeiza12), and nine CIMMYT genotypes (Lee, Otane, Jupateco-73-R, Pavon-F-76, Opata-85, Janz, Gatcher, Amigo, Exchange), followed by the second categorized nine cultivars, Sids-13, Sids-14 (Egyptian cvs), Super-Kauz, Hussar, Manitou, Kenya-Sunbird, Kiskadee-1, Transec, Quaiu-1 (CIMMYT genotypes) which exhibited DI less than 40 during both years. Twelve cvs recorded DI less than 60 during both years, including five Egyptian cvs (Sakha-95, Gemmeiza-10, Beniswef-1, Beniswef-3, Beniswef-4) and seven CIMMYT genotypes (Jupateco-73-S, Tatara, Trident, Thew, Grackle-1, Becard-1, Eagle). The remaining genotypes exhibited DI more than 60 during both years.

For leaf rust, the first category consisted of 26 genotypes with the lowest $\mathrm{Cl}$ values (up to 20) during both years, including, 11 Egyptian cvs (Misr-1, Misr-2, Misr-3, Sakha-93, Sakha-94, Sakha-95, Giza-168, Giza171, Sids-13, Sids-14, Shandweel-1) and 15 CIMMYT genotypes (Lee, Otane Jupateco-73-R, Pavon-F-76, Opata85, Super-Kauz, Tatara, Janz, Gatcher, Hussar, Kenya-Sunbird, Thew, Kiskadee-1, Chewink-1, Exchange). Ten genotypes occupied the second category with $\mathrm{Cl}$ less than 40 during both years, including five Egyptian cvs (Gemmeiza-9, Gemmeiza-10, Gemmeiza-11, Gemmeiza-12, Beniswef-1) and five CIMMYT genotypes (Clement, Jupateco-73-S, Manitou, Amigo, Quaiu-1). Four cultivars, Sids-12, Heines-Peko, Trident, Transec and Grackle-1, displayed $\mathrm{Cl}$ up tp 60 during both years. The remaining genotypes exhibited $\mathrm{Cl}$ more than 60 during both years. The values of $\mathrm{DI}$ and $\mathrm{Cl}$ were parallel during both years except DI values of Gemmeiza-9 and Sids-12 as well as $\mathrm{Cl}$ values of Beniswef-4 and Eagle. The check susceptible genotypes, Chancellor and Morocco recorded the highest values of $\mathrm{DI}$ and $\mathrm{Cl}$ with 88.88 and 90.00 , respectively. 
Table 2. Incubation period (IP) and latent period (LP) for powdery mildew and leaf rust in Egyptian and CIMMYT wheat genotypes separately inoculated with bulk isolates of Blumeria graminis f. sp. tritici and Puccinia triticina at seedlings stage.

\begin{tabular}{|c|c|c|c|c|c|}
\hline \multirow[t]{2}{*}{ Entry } & \multirow[t]{2}{*}{ Genotype } & \multicolumn{2}{|c|}{ Powdery mildew } & \multicolumn{2}{|c|}{ Leaf rust } \\
\hline & & IP (d)* & LP (d) & IP (d) & $\operatorname{LP}(d)$ \\
\hline \multirow{20}{*}{ 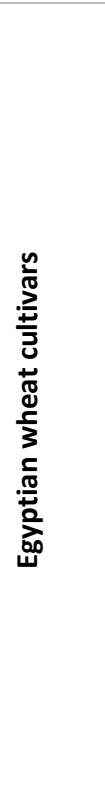 } & Misr-1 & 9 & 11 & 9 & 12 \\
\hline & Misr-2 & 9 & 12 & 9 & 13 \\
\hline & Misr-3 & 9 & 11 & 9 & 12 \\
\hline & Sakha-93 & 6 & 8 & 8 & 11 \\
\hline & Sakha-94 & 6 & 8 & 9 & 11 \\
\hline & Sakha-95 & 7 & 9 & 7 & 9 \\
\hline & Giza-168 & 8 & 11 & 9 & 11 \\
\hline & Giza-171 & 9 & 12 & 9 & 12 \\
\hline & Gemmeiza-9 & 6 & 8 & 7 & 8 \\
\hline & Gemmeiza-10 & 6 & 8 & 7 & 9 \\
\hline & Gemmeiza-11 & 7 & 9 & 6 & 8 \\
\hline & Gemmeiza-12 & 9 & 11 & 6 & 8 \\
\hline & Sids-12 & 7 & 9 & 6 & 8 \\
\hline & Sids-13 & 8 & 10 & 9 & 12 \\
\hline & Sids-14 & 8 & 11 & 9 & 13 \\
\hline & Shandweel-1 & 6 & 8 & 9 & 11 \\
\hline & Beniswef-1 & 8 & 10 & 8 & 10 \\
\hline & Beniswef-3 & 7 & 9 & 7 & 8 \\
\hline & Beniswef-4 & 8 & 10 & 8 & 11 \\
\hline & Sohag-3 & 6 & 8 & 7 & 8 \\
\hline \multirow{26}{*}{ 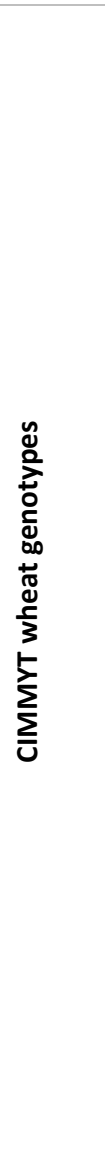 } & Clement & 7 & 9 & 8 & 10 \\
\hline & Heines-Peko & 7 & 9 & 7 & 9 \\
\hline & Lee & 9 & 11 & 9 & 12 \\
\hline & Otane & 8 & 10 & 9 & 13 \\
\hline & Jupateco-73-R & 9 & 11 & 9 & 13 \\
\hline & Jupateco-73-S & 8 & 10 & 8 & 10 \\
\hline & Pavon-F-76 & 9 & 11 & 9 & 13 \\
\hline & Opata-85 & 9 & 12 & 9 & 13 \\
\hline & Super-Kauz & 8 & 10 & 9 & 12 \\
\hline & Tatara & 8 & 10 & 7 & 9 \\
\hline & Janz & 8 & 10 & 9 & 13 \\
\hline & Gatcher & 9 & 11 & 7 & 9 \\
\hline & Trident & 7 & 9 & 6 & 8 \\
\hline & Hussar & 9 & 11 & 9 & 11 \\
\hline & Manitou & 7 & 9 & 8 & 10 \\
\hline & Kenya-Sunbird & 8 & 10 & 9 & 12 \\
\hline & Amigo & 8 & 10 & 8 & 10 \\
\hline & Thew & 9 & 12 & 9 & 13 \\
\hline & Kiskadee-1 & 9 & 11 & 9 & 13 \\
\hline & Chewink-1 & 9 & 11 & 9 & 12 \\
\hline & Transec & 8 & 10 & 8 & 10 \\
\hline & Grackle-1 & 7 & 9 & 7 & 9 \\
\hline & Becard-1 & 7 & 9 & 7 & 8 \\
\hline & Eagle & 8 & 10 & 8 & 11 \\
\hline & Exchange & 9 & 11 & 9 & 12 \\
\hline & Quaiu-1 & 9 & 11 & 9 & 12 \\
\hline \multirow[t]{2}{*}{ Check } & Chancellor & 6 & 8 & - & - \\
\hline & Morocco & - & - & 6 & 8 \\
\hline
\end{tabular}


Table 3. Disease index (DI) for powdery mildew and coefficient of infection (CI) for leaf rust in Egyptian and CIMMYT wheat cultivars recorded in 2019 and 2020 at El-Sabahia Agricultural Research Station, Alexandria.

\begin{tabular}{|c|c|c|c|c|c|}
\hline \multirow[t]{2}{*}{ Entry } & \multirow[t]{2}{*}{ Genotype } & \multicolumn{2}{|c|}{ Powdery mildew (DI) } & \multicolumn{2}{|c|}{ Leaf rust $(\mathrm{Cl})$} \\
\hline & & 2019 & 2020 & 2019 & 2020 \\
\hline \multirow{20}{*}{ 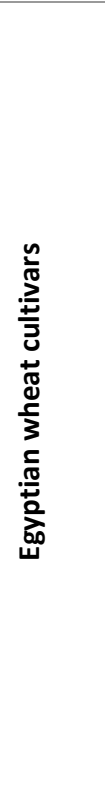 } & Misr-1 & 12.34 & 19.75 & 4 & 8 \\
\hline & Misr-2 & 19.75 & 18.81 & 4 & 8 \\
\hline & Misr-3 & 14.81 & 18.81 & 2 & 4 \\
\hline & Sakha-93 & 60.49 & 66.66 & 8 & 8 \\
\hline & Sakha-94 & 69.13 & 77.77 & 8 & 8 \\
\hline & Sakha-95 & 43.20 & 43.20 & 8 & 16 \\
\hline & Giza-168 & 14.81 & 12.34 & 4 & 8 \\
\hline & Giza-171 & 12.34 & 14.81 & 4 & 8 \\
\hline & Gemmeiza-9 & 44.44 & 34.56 & 30 & 30 \\
\hline & Gemmeiza-10 & 44.44 & 43.20 & 40 & 40 \\
\hline & Gemmeiza-11 & 34.56 & 43.20 & 30 & 40 \\
\hline & Gemmeiza-12 & 14.81 & 19.75 & 40 & 40 \\
\hline & Sids-12 & 43.20 & 34.56 & 60 & 60 \\
\hline & Sids-13 & 24.69 & 29.62 & 8 & 8 \\
\hline & Sids-14 & 22.22 & 24.29 & 4 & 4 \\
\hline & Shandweel-1 & 66.66 & 69.13 & 4 & 8 \\
\hline & Beniswef-1 & 43.20 & 44.44 & 30 & 30 \\
\hline & Beniswef-3 & 51.85 & 56.66 & 70 & 70 \\
\hline & Beniswef-4 & 44.44 & 43.20 & 40 & 50 \\
\hline & Sohag-3 & 60.49 & 66.66 & 70 & 70 \\
\hline \multirow{26}{*}{ 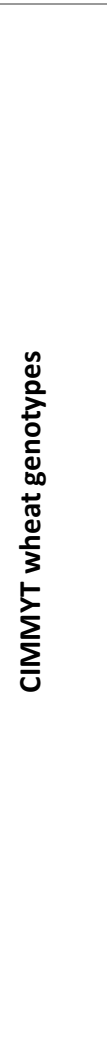 } & Clement & 60.49 & 66.66 & 40 & 40 \\
\hline & Heines-Peko & 66.49 & 69.13 & 60 & 60 \\
\hline & Lee & 14.81 & 18.81 & 12 & 16 \\
\hline & Otane & 19.75 & 18.81 & 4 & 8 \\
\hline & Jupateco-73-R & 14.81 & 19.75 & 8 & 8 \\
\hline & Jupateco-73-S & 51.85 & 56.66 & 24 & 24 \\
\hline & Pavon-F-76 & 14.81 & 12.34 & 4 & 8 \\
\hline & Opata-85 & 12.34 & 14.81 & 8 & 8 \\
\hline & Super-Kauz & 24.69 & 29.62 & 16 & 16 \\
\hline & Tatara & 43.20 & 44.44 & 20 & 20 \\
\hline & Janz & 19.75 & 18.81 & 8 & 16 \\
\hline & Gatcher & 14.81 & 19.75 & 20 & 20 \\
\hline & Trident & 43.20 & 43.20 & 60 & 60 \\
\hline & Hussar & 22.22 & 24.69 & 20 & 20 \\
\hline & Manitou & 29.62 & 34.56 & 24 & 24 \\
\hline & Kenya-Sunbird & 24.69 & 29.62 & 20 & 20 \\
\hline & Amigo & 12.34 & 14.81 & 24 & 24 \\
\hline & Thew & 43.20 & 44.44 & 8 & 8 \\
\hline & Kiskadee-1 & 22.22 & 24.29 & 8 & 8 \\
\hline & Chewink-1 & 60.66 & 66.66 & 8 & 8 \\
\hline & Transec & 30.86 & 37.03 & 50 & 50 \\
\hline & Grackle-1 & 43.20 & 44.44 & 50 & 50 \\
\hline & Becard-1 & 51.85 & 56.66 & 70 & 70 \\
\hline & Eagle & 44.44 & 43.20 & 40 & 50 \\
\hline & Exchange & 19.75 & 18.81 & 16 & 16 \\
\hline & Quaiu-1 & 24.29 & 29.62 & 24 & 24 \\
\hline \multirow[t]{2}{*}{ Check } & Chancellor & 88.88 & 88.88 & - & - \\
\hline & Morocco & - & - & 90 & 90 \\
\hline \multicolumn{2}{|c|}{ LSD (0.05) for genotypes } & \multicolumn{2}{|c|}{2.74} & \multicolumn{2}{|c|}{3.42} \\
\hline \multicolumn{2}{|c|}{ CV\% for genotypes } & \multicolumn{2}{|c|}{4.80} & \multicolumn{2}{|c|}{8.51} \\
\hline
\end{tabular}

Data illustrated in Figures (1 and 2 ) showed the average disease index (ADI) for powdery mildew and the average coefficient of infection ACl for leaf rust during both years 2019 and 2020 in the tested Egyptian and CIMMYT wheat genotypes, respectively. Data revealed the presence of the lowest values of ADI and ACI (less than 20) in five Egyptian cvs, Misr-1, Misr-2, Misr-3, Giza-168 and Giza-171, followed by cvs Gemmeiza-9, Gemmeiza-11 (less than 40) and Beniswef-4 (less than 60) (Fig. 1). While they were present in eight CIMMYT 
genotypes, Lee, Otane, Jupateco-73-R, Pavon-F-76, Opata-85, Janz, Gatcher, Exchange (less than 20), followed by Manitou, Quaiu-1 (less than 40) and Eagle (less than 60) (Fig. 2).

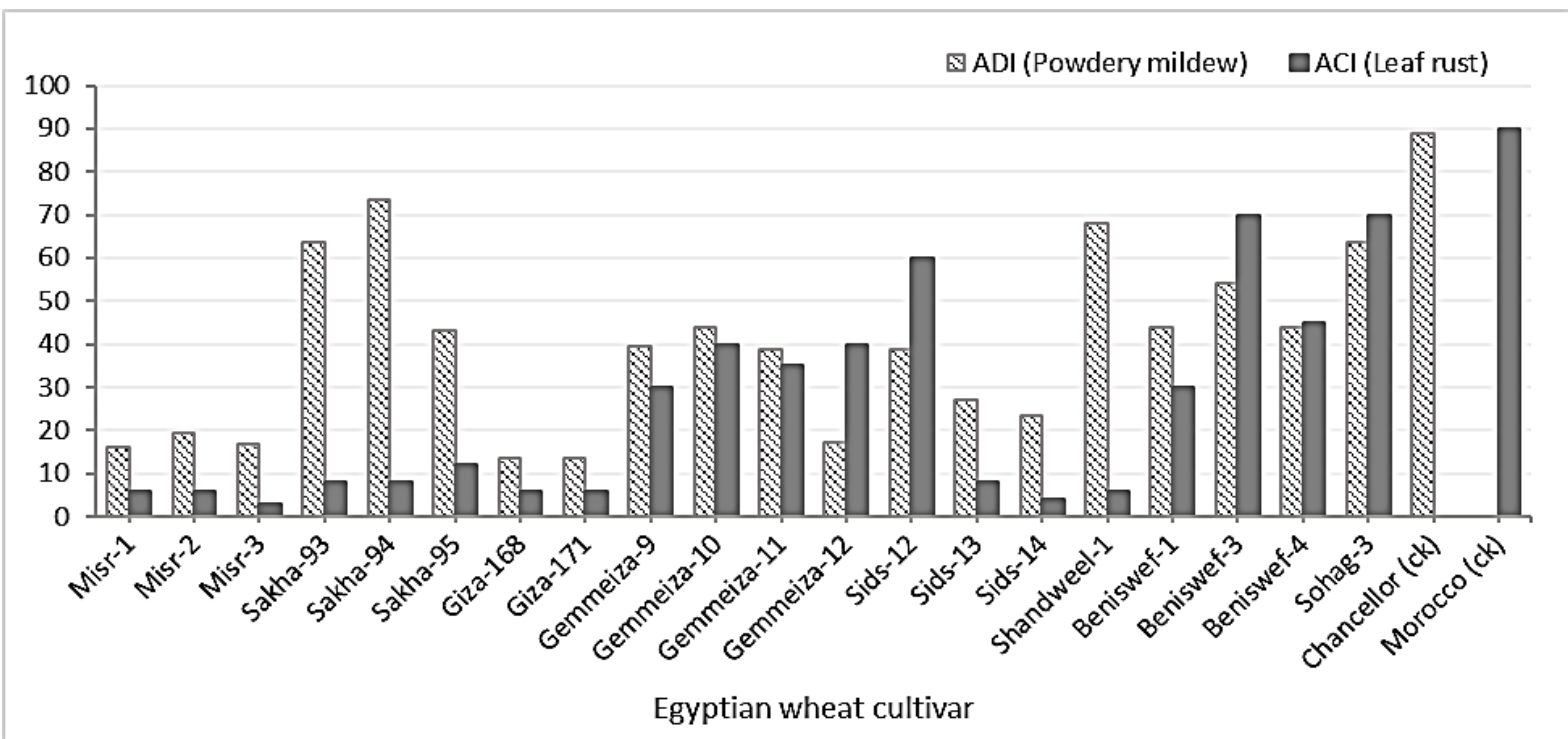

Fig. 1. Average disease index (ADI) for powdery mildew and average coefficient of infection ( $A C l$ ) for leaf rust of twenty Egyptian wheat cultivars during both years 2019 and 2020 at El-Sabahia Agricultural Research Station, Alexandria.

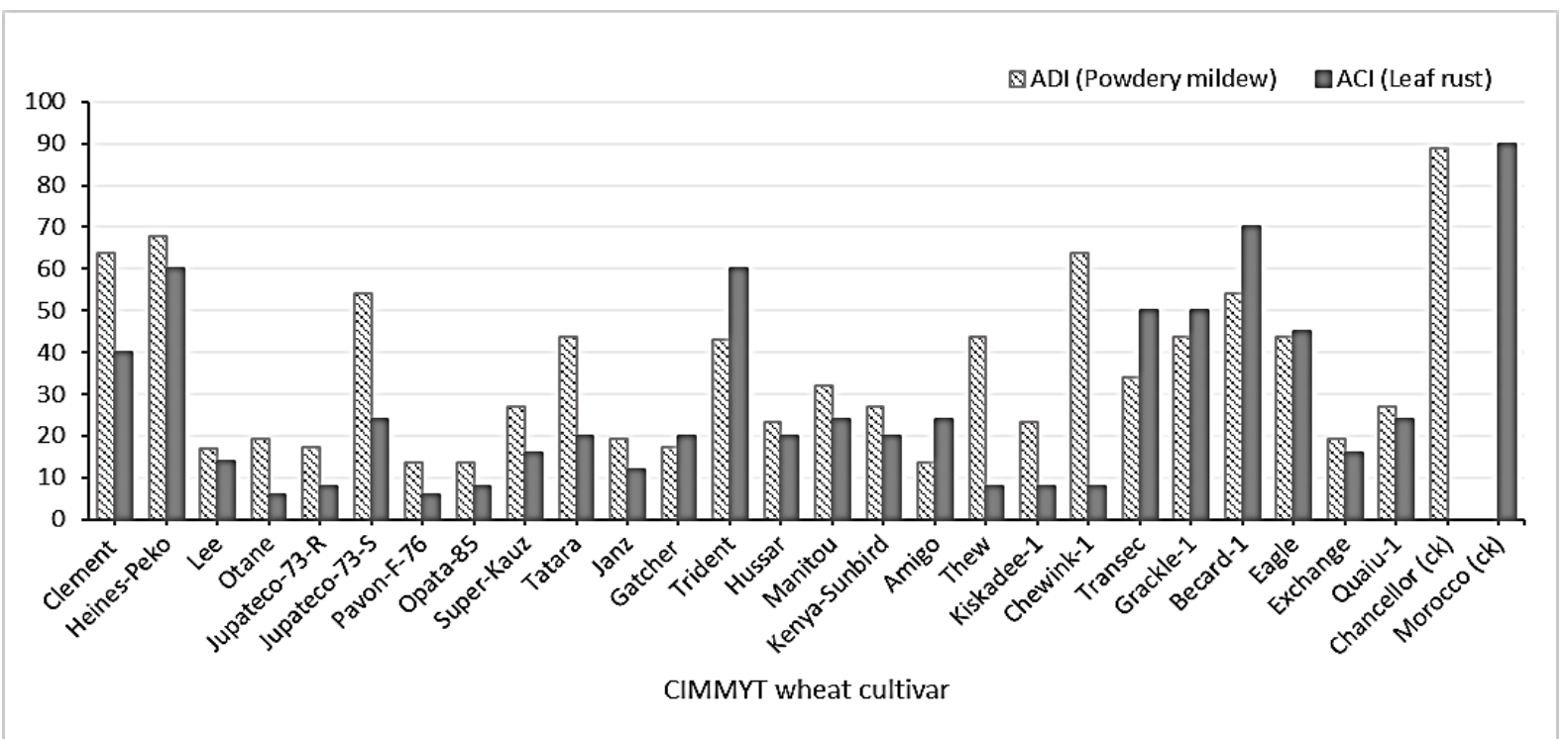

Fig. 2. Average disease index (ADI) for powdery mildew and average coefficient of infection (ACI) for leaf rust of twenty-six CIMMYT wheat cultivars during both years 2019 and 2020 at El-Sabahia Agricultural Research Station, Alexandria.

Data in Table (4) revealed the variability in the AUDPC values for each of powdery mildew and leaf rust among genotypes, but the consistency of the values was observed during both years 2019 and 2020. Analysis of variance of AUDPC indicated highly significant differences between the performances of different genotypes. The AUDPC values ranged from 60.00 to 1235.00 for powdery mildew, while it ranged from 22.10 to 876.66 for leaf rust. Genotypes could be classified into three categories; genotypes with AUDPC values up to 300, genotypes with AUDPC values up to 600 and genotypes with AUDPC values above 600. For powdery mildew, the first category consisted of 25 genotypes exhibited AUDPC values up to 300, including nine Egyptian cvs, Misr-1, Misr-2, Misr-3, Giza-168, Giza-171, Gemmeiza-12, Sids-12, Sids-13, Sids-14, and 16 CIMMYT genotypes, Clement, Lee, Otane, Jupateco-73-R, Pavon-F-76, Opata-85, Super-Kauz, Tatara, Janz, Gatcher, Hussar, Kenya-Sunbird, Amigo, Thew, Exchange, Quaiu-1. Eight genotypes, Beniswef-1, Beniswef-4, Manitou, Kiskadee-1, Chewink-1, Transec, Grackle-1 and Eagle involved in the second category recording AUDPC values up to 600. However, the remaining genotypes showed values above 600. For leaf rust, 27 genotypes exhibited values less than 300, including 11 Egyptian cvs, Misr-1, Misr-2, Misr-3, Sakha-93, Sakha-94, Sakha-95, Giza-168, Giza-171, Sids-13, Sids-14, Shandweel-1, and 16 CIMMYT genotypes, Lee, Otane, Jupateco-73-R, Jupateco-73-S, Pavon-F-76, Opata-85, Super-Kauz, Tatara, Janz, Manitou, KenyaSunbird, Thew, Kiskadee-1, Chewink-1, Exchange and Quaiu-1. Fourteen genotypes came in the second category with values less than 600, including six Egyptian cvs, Gemmieza-9, Gemmieza-10 and Gemmeiza-11, Beniswef-1, Beniswef-3, Beniswef-4 
and eight CIMMYT cvs, Clement, Gatcher, Hussar, Amigo, Transec, Grackle-1, Becard-1 and Eagle. The remaining genotypes showed values above 600 . The check susceptible genotypes, Chancellor and Morocco showed the highest values reached 1263.33 and 1345.33 in the second year, respectively.

Table 4. Area under disease progress curve (AUDPC) for powdery mildew and leaf rust in Egyptian and CIMMYT wheat cultivars recorded in 2019 and 2020 at El-Sabahia Agricultural Research Station, Alexandria.

\begin{tabular}{|c|c|c|c|c|c|}
\hline \multirow[t]{2}{*}{ Entry } & \multirow[t]{2}{*}{ Genotype } & \multicolumn{2}{|c|}{ AUDPC Powdery mildew } & \multicolumn{2}{|c|}{ AUDPC Leaf rust } \\
\hline & & 2019 & 2020 & 2019 & 2020 \\
\hline \multirow{20}{*}{ 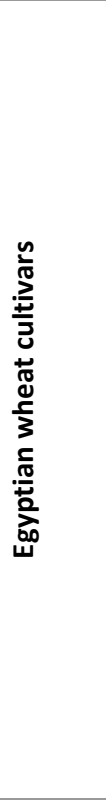 } & Misr-1 & 60.00 & 83.33 & 28.40 & 61.83 \\
\hline & Misr-2 & 121.66 & 161.66 & 32.20 & 67.00 \\
\hline & Misr-3 & 121.66 & 161.66 & 22.40 & 32.20 \\
\hline & Sakha-93 & 1105.00 & 1166.66 & 101.06 & 99.33 \\
\hline & Sakha-94 & 1195.00 & 1235.00 & 118.66 & 104.00 \\
\hline & Sakha-95 & 615.00 & 665.00 & 41.00 & 159.00 \\
\hline & Giza-168 & 158.33 & 161.66 & 41.00 & 81.66 \\
\hline & Giza-171 & 79.00 & 81.00 & 32.20 & 77.00 \\
\hline & Gemmeiza-9 & 866.66 & 840.00 & 314.00 & 325.33 \\
\hline & Gemmeiza-10 & 610.00 & 677.00 & 461.66 & 455.16 \\
\hline & Gemmeiza-11 & 621.66 & 605.00 & 385.00 & 422.33 \\
\hline & Gemmeiza-12 & 154.00 & 174.00 & 650.00 & 651.66 \\
\hline & Sids-12 & 248.33 & 234.00 & 830.83 & 876.66 \\
\hline & Sids-13 & 179.00 & 210.66 & 139.26 & 190.00 \\
\hline & Sids-14 & 133.66 & 156.33 & 28.40 & 41.00 \\
\hline & Shandweel-1 & 842.33 & 882.33 & 41.00 & 81.66 \\
\hline & Beniswef-1 & 515.00 & 565.00 & 314.00 & 325.33 \\
\hline & Beniswef-3 & 645.00 & 660.00 & 385.00 & 422.33 \\
\hline & Beniswef-4 & 566.66 & 540.00 & 314.00 & 325.33 \\
\hline & Sohag-3 & 866.66 & 840.00 & 650.00 & 651.66 \\
\hline \multirow{26}{*}{ 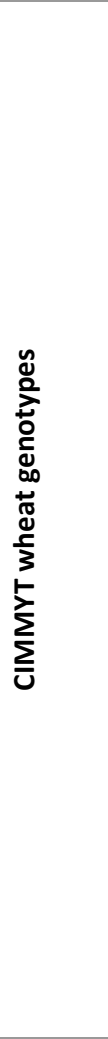 } & Clement & 179.00 & 210.66 & 385.00 & 422. 33 \\
\hline & Heines-Peko & 645.00 & 660.00 & 830.83 & 876.66 \\
\hline & Lee & 121.66 & 161.66 & 63.16 & 67.00 \\
\hline & Otane & 158.33 & 161.66 & 41.00 & 81.66 \\
\hline & Jupateco-73-R & 179.00 & 210.66 & 118.66 & 104.00 \\
\hline & Jupateco-73-S & 615.00 & 665.00 & 139.26 & 159.00 \\
\hline & Pavon-F-76 & 60.00 & 83.33 & 38.22 & 61.83 \\
\hline & Opata-85 & 79.00 & 81.00 & 75.33 & 77.00 \\
\hline & Super-Kauz & 179.00 & 210.66 & 139.26 & 190.00 \\
\hline & Tatara & 161.66 & 210.66 & 104.00 & 139.26 \\
\hline & Janz & 179.00 & 179.00 & 139.26 & 190.00 \\
\hline & Gatcher & 158.33 & 174.00 & 385.00 & 422.33 \\
\hline & Trident & 866.66 & 840.00 & 830.83 & 876.66 \\
\hline & Hussar & 154.00 & 179.00 & 422.33 & 422.33 \\
\hline & Manitou & 515.00 & 540.00 & 118.66 & 139.26 \\
\hline & Kenya-Sunbird & 179.00 & 210.66 & 139.26 & 190.00 \\
\hline & Amigo & 60.00 & 83.33 & 385.00 & 422.33 \\
\hline & Thew & 210.66 & 210.66 & 77.00 & 81.66 \\
\hline & Kiskadee-1 & 515.00 & 565.00 & 75.33 & 77.00 \\
\hline & Chewink-1 & 566.66 & 540.00 & 75.33 & 77.00 \\
\hline & Transec & 540.00 & 565.00 & 422.33 & 480.13 \\
\hline & Grackle-1 & 515.00 & 565.00 & 314.00 & 325.33 \\
\hline & Becard-1 & 645.00 & 660.00 & 385.00 & 422.33 \\
\hline & Eagle & 566.66 & 540.00 & 314.00 & 325.33 \\
\hline & Exchange & 60.00 & 83.33 & 58.66 & 61.83 \\
\hline & Quaiu-1 & 158.33 & 161.66 & 41.00 & 81.66 \\
\hline \multirow[t]{2}{*}{ Check } & Chancellor & 1230.00 & 1263.33 & - & - \\
\hline & Morocco & - & - & 1233.5 & 1345.33 \\
\hline \multicolumn{2}{|c|}{ LSD (0.05) for genotypes } & \multicolumn{2}{|c|}{8.19} & \multicolumn{2}{|c|}{13.46} \\
\hline \multicolumn{2}{|c|}{ CV\% for genotypes } & \multicolumn{2}{|c|}{1.27} & \multicolumn{2}{|c|}{3.31} \\
\hline
\end{tabular}

Values up to $300=$ high level of partial resistance, values $>300$ to $600=$ low level of partial resistance, values above $600=$ absence of partial resistance 
Data illustrated in Figures (3 and 4 ) revealed the relative area under disease progress curve ( $r$-AUDPC) for powdery mildew and leaf rust recorded during both years 2019 and 2020 in the tested Egyptian and CIMMYT wheat genotypes, respectively. Data indicated that seven Egyptian cvs, Misr-1, Misr-2, Misr-3, Giza-168, Giza-171, Sids-13, Sids-14 (Fig. 3) and ten CIMMYT genotypes, Lee, Otane, Pavon-F-76, Opata-85, Tatara, Janz, Gatcher, Kenya-Sunbird, Exchange, Quaiu-1 (Fig. 4), recorded the lowest values of $r$-AUDPC (up to 30.00).

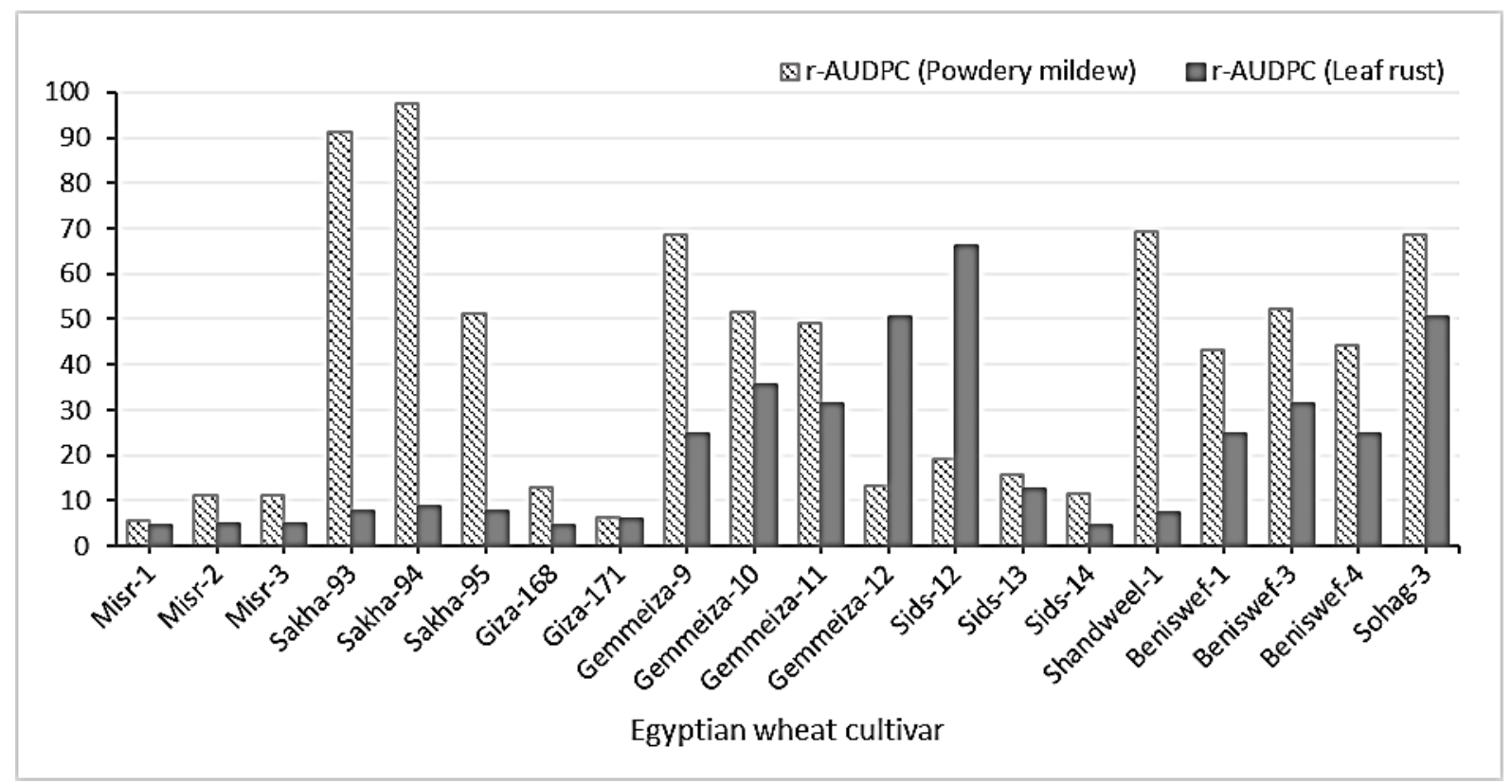

Fig. 3. Relative area under disease progress curve ( $r$-AUDPC) for powdery mildew and leaf rust of twenty Egyptian wheat cultivars during both years 2019 and 2020 at El-Sabahia Agricultural Research Station, Alexandria. Susceptible check genotypes; Chancellor for powdery mildew and Morocco for leaf rust.

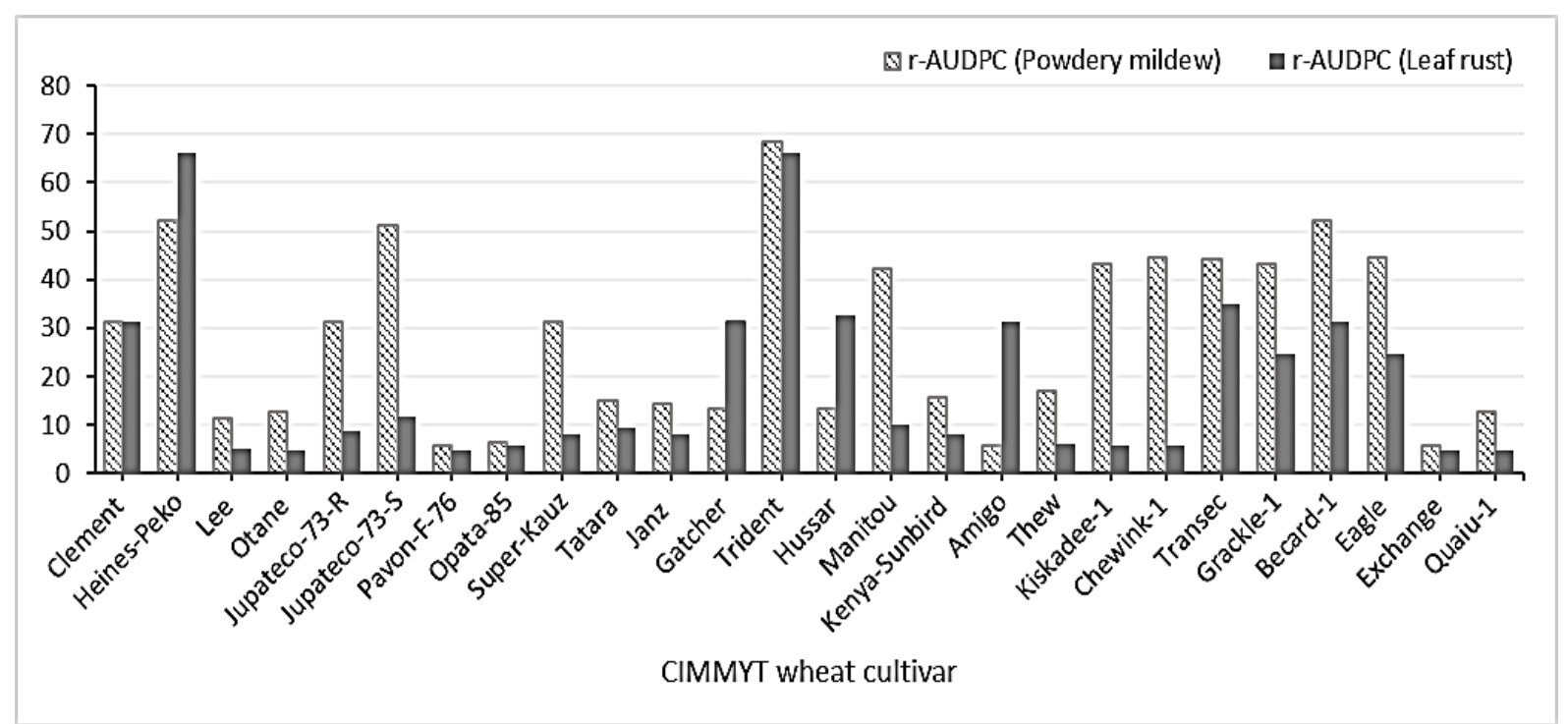

Fig. 4. Relative area under disease progress curve (r-AUDPC) for powdery mildew and leaf rust of twenty-six CIMMYT wheat cultivars during both years 2019 and 2020 at El-Sabahia Agricultural Research Station, Alexandria. Susceptible check genotypes; Chancellor for powdery mildew and Morocco for leaf rust.

\section{Partial resistance traits relationship:}

The correlation coefficient ( $r$ ) was calculated among seedling partial resistance traits (IP, LP) and adult plant partial resistance traits (ADI, ACl, $r$-AUDPC). Data illustrated in Figure (5) revealed a strong inverse correlation between incubation period (IP) and average disease index (ADI) as well as between LP and ADI for powdery mildew in the tested Egyptian and CIMMYT wheat genotypes. Likewise, data illustrated in Figure (6) revealed a strong inverse correlation between IP and ACl as well as LP and $\mathrm{ACl}$ for leaf rust in the tested Egyptian and CIMMYT wheat genotypes.

A strong inverse correlation was also observed between IP and $r$-AUDPC as well as between LP and $r$-AUDPC for powdery mildew (Fig. 7). Likewise, a strong inverse correlation was observed between IP and $r$-AUDPC as well as between LP and $r$ - 
AUDPC for leaf rust (Fig. 8). However, data given in Figure (9) revealed a strong direct correlation between ADI and $r$-AUDPC for powdery mildew as well as between $\mathrm{ACl}$ and $r$-AUDPC for leaf rust.
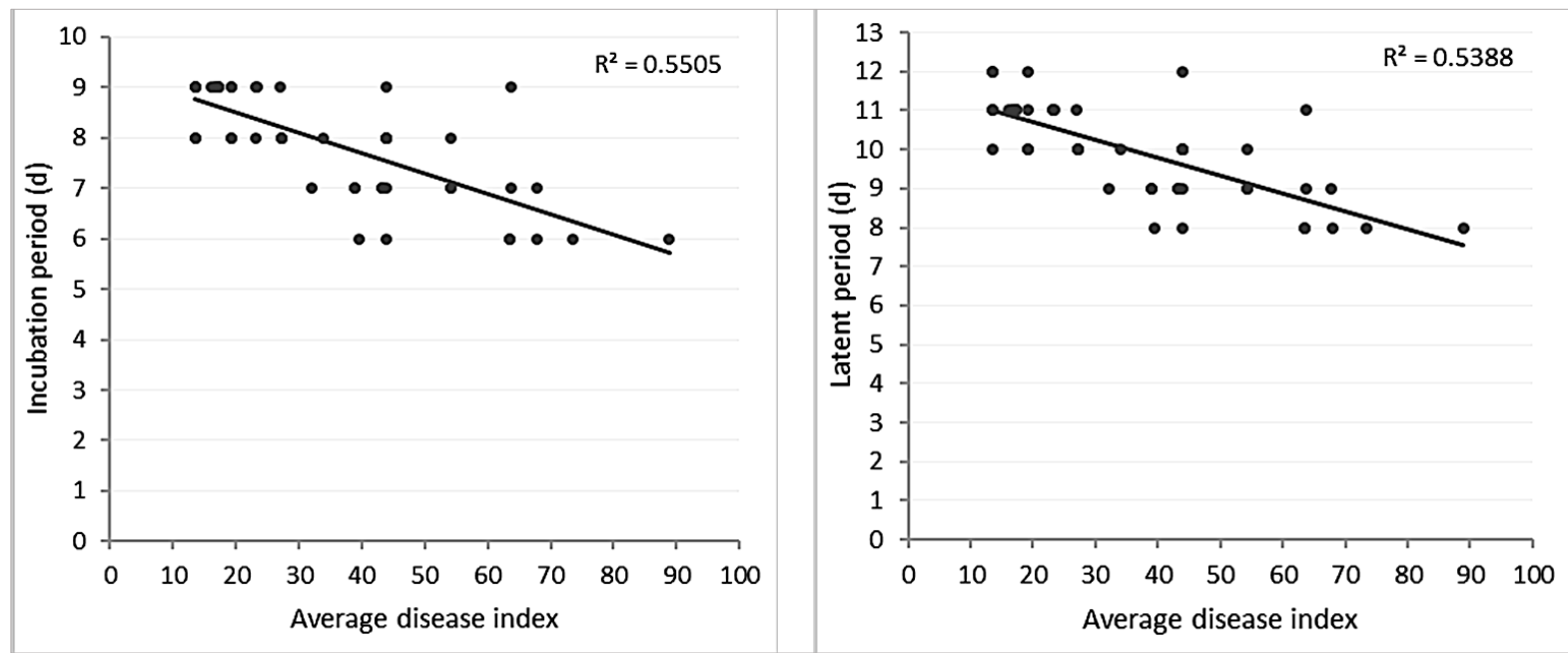

Fig. 5. Correlation between incubation period (IP), latent period (LP) and average disease index (ADI) for powdery mildew in the tested Egyptian and CIMMYT wheat genotypes.
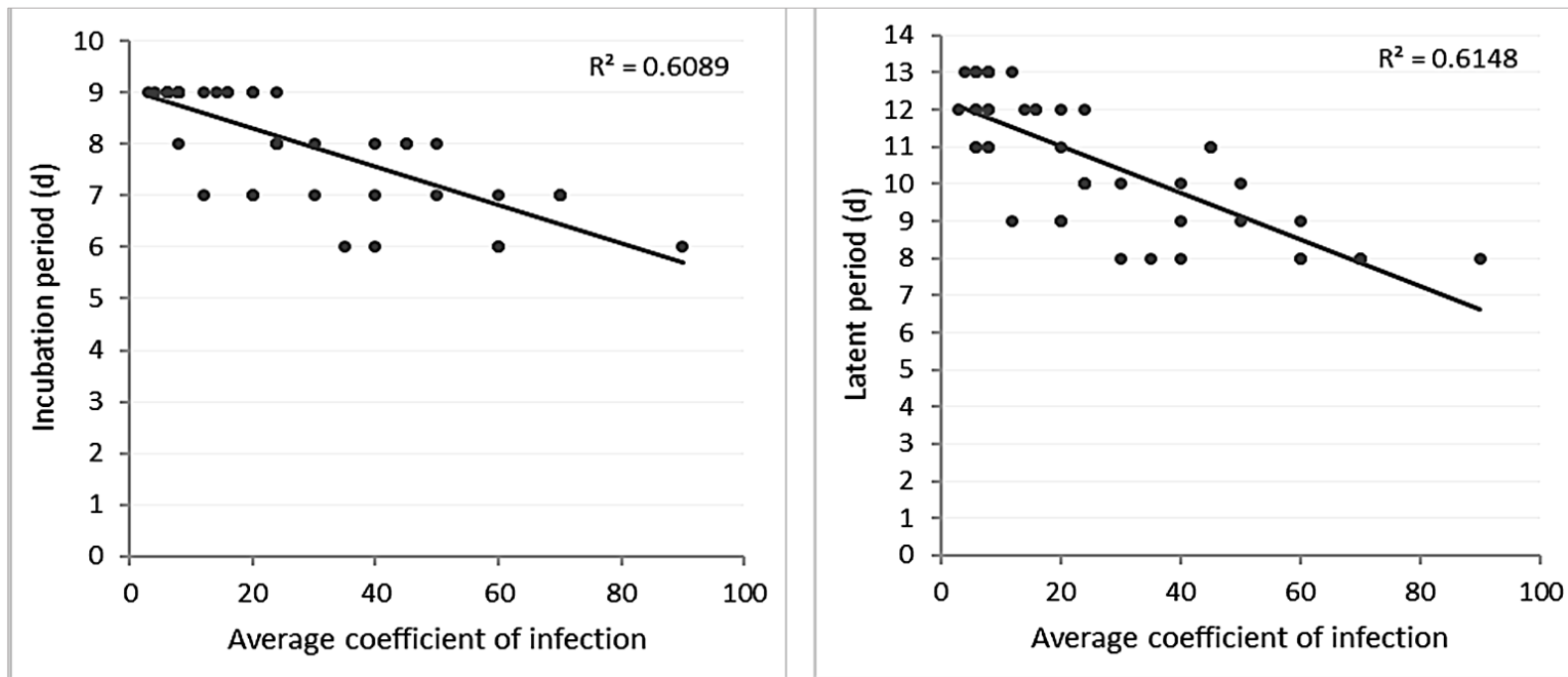

Fig. 6. Correlation between incubation period (IP), latent period (LP) and average coefficient of index (ACI) leaf rust in the tested Egyptian and CIMMYT wheat genotypes.
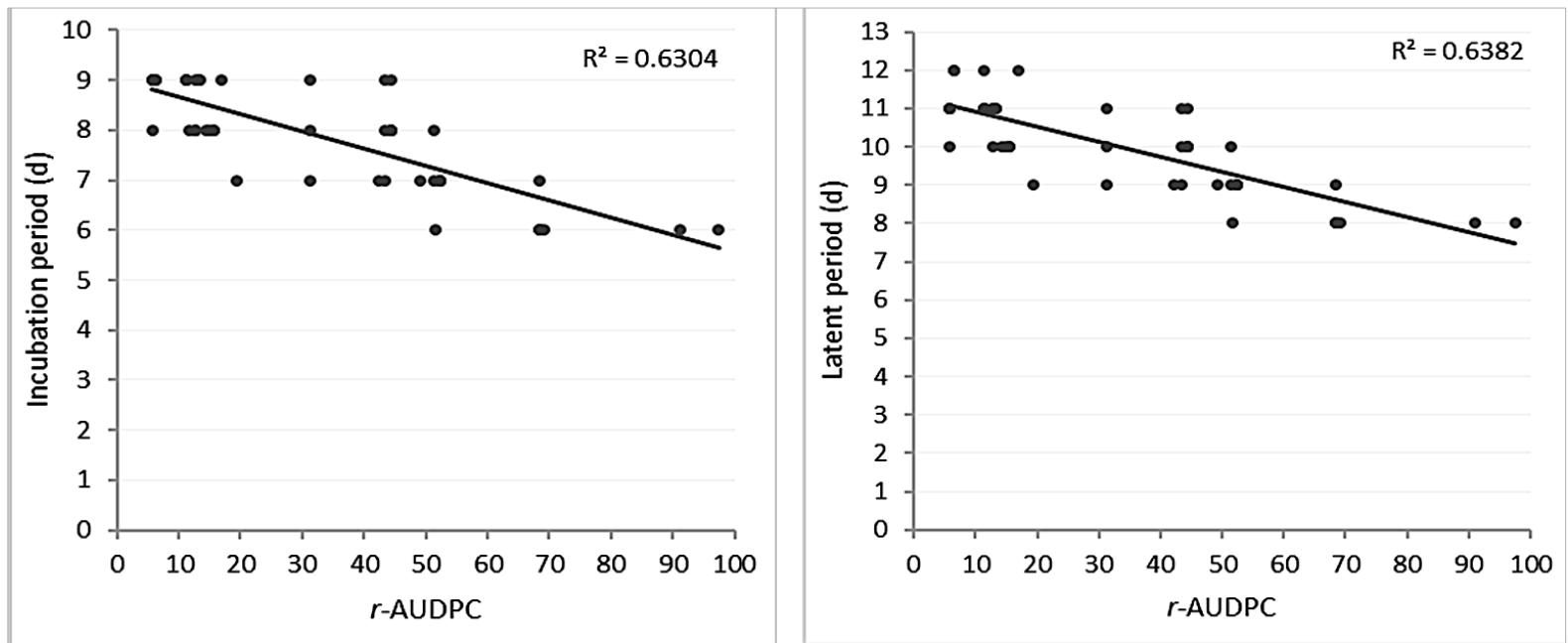

Fig. 7. Correlation between incubation period (IP), latent period (LP) and relative area under disease progress curve $(r$ AUDPC) for powdery mildew in the tested Egyptian and CIMMYT wheat genotypes. 

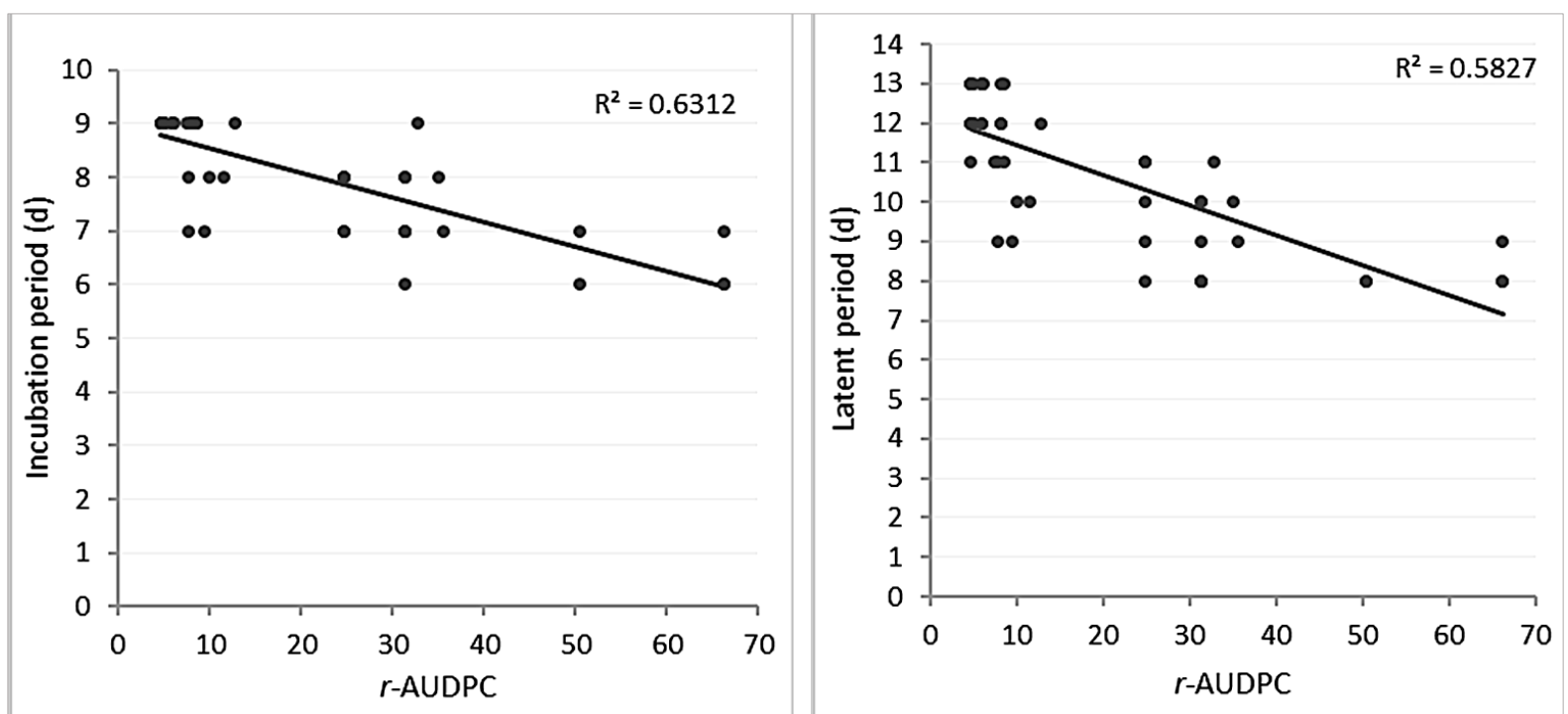

Fig. 8. Correlation between incubation period (IP), latent period (LP) and relative area under disease progress curve $(r$ AUDPC) for leaf rust in the tested Egyptian and CIMMYT wheat genotypes.
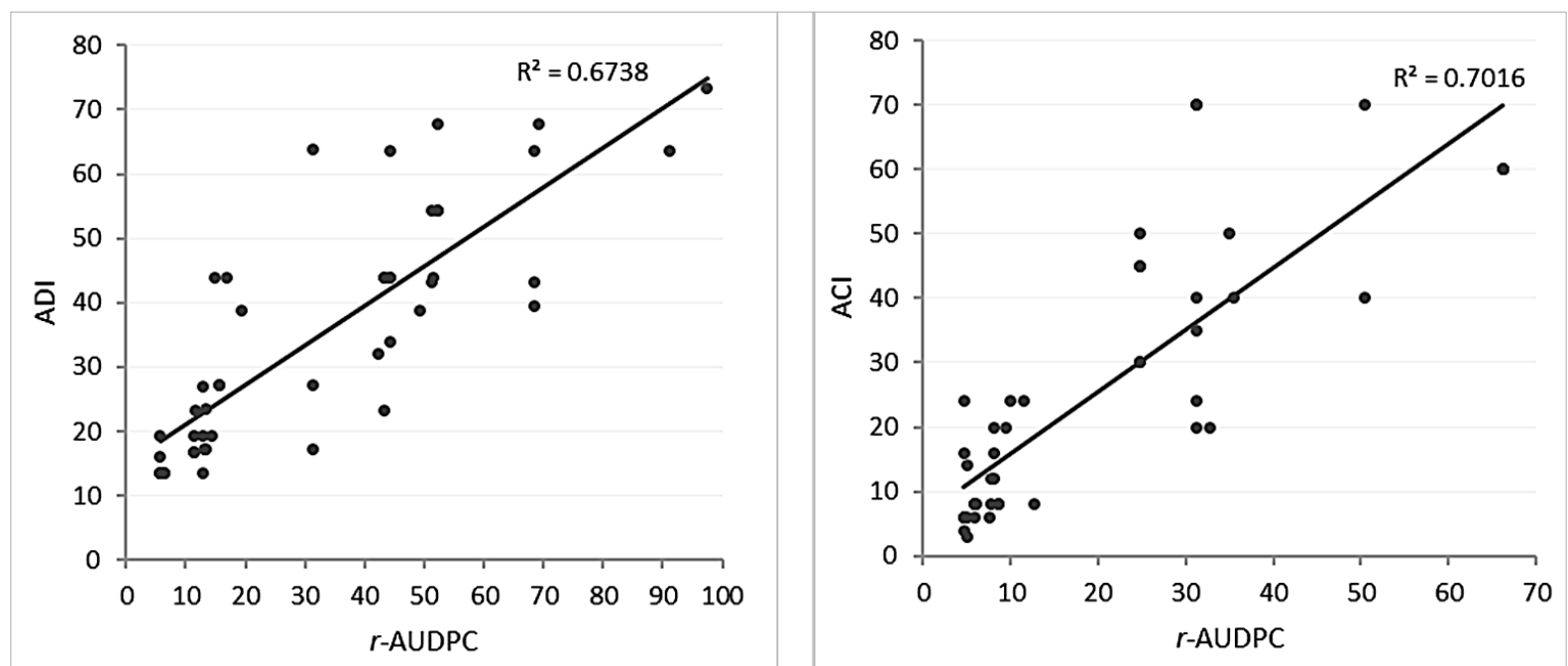

Fig. 9. Correlation between average disease index ( $A D I)$, average coefficient of infection ( $A C I$ ) and relative area under disease progress curve ( $r$-AUDPC) for powdery mildew and leaf rust in the tested Egyptian and CIMMYT wheat genotypes.

\section{DISCUSSION}

Partial resistance to powdery mildew and leaf rust is likely to be a significant goal for Egyptian wheat breeding programmes because this type of resistance has provided durable mildew and rust control in cereals in several countries (Shaner 1973; Bennett 1984; Jones and Davies 1985; Das et al., 1993; Yu et al., 2001; Kolmer et al., 2008). The use of field scores alone to classify partial resistance to both diseases may be unreliable, however, because a cultivar may have low powdery mildew and leaf rust severities either because it has partial resistance or because it has race-specific resistance effective against a large fraction of the pathogen population (Yu et al., 2001; Das et al., 1993). Cultivars that suffer relatively low levels of mildew and rust despite a high frequency of the corresponding virulence in the pathogen population may have good partial resistance and may be used as mildew and rust-resistant germplasm in breeding programmes. Parameters that may be used to quantify seedling partial resistance are infection frequency, incubation period, latent period and sporulation intensity (Parlevliet 1975; Kranz 1983). The 46 Egyptian and CIMMYT wheat genotypes tested here varied greatly in partial resistance to powdery mildew and leaf rust. Egyptian cultivars, Misr-1, Misr-2, Misr-3, Giza-171 and CIMMYT genotypes, Jupateco-73-R, Pavon-F-76, Opata-85, Thew, Kiskadee-1, Chewink-1, Exchange, Quaiu-1 performed consistently well concerning partial resistance to both diseases at the seedling stage. They were susceptible to a large proportion of isolates the B. graminis f. sp. tritici (Bgt) and Puccinia triticina (Pt) collected from different places and different years, but they recorded the longest incubation period (IP) and latent period (LP) at the seedling stage. They, therefore, appear to have good partial resistance to both diseases (ElShamy et al., 2012; Draz et al., 2015; Abdelrhim et al., 2018).

In the field trials, investigation of adult plant partial resistance was done here based on disease index (DI) and coefficient of infection $(\mathrm{Cl})$, and therefore, $\mathrm{ADI}$ and $\mathrm{ACl}$. Although they are useful in characterizing partial resistance, $\mathrm{ADI}$ and $\mathrm{ACl}$ cannot 
be the only variable used to evaluate partial resistance when both partial resistance and effective race-specific resistance are present in a large set of cultivars. The AUDPC and $r$-AUDPC were also calculated to assess the partial resistance at adult plant stages. Partial resistance allows some epidemic development of the disease, but at a reduced level (Knudsen et al., 1986). The quantitative nature of the resistance means that it is more difficult to identify than race-specific resistance, but it may be apparent as relatively low disease severity under high disease pressure (Yu et al., 2001; Das et al., 1993; Pandey et al., 1989). A low ADI, ACl, AUDPC and $r$-AUDPC implies that the rate of epidemic development is reduced. Seven Egyptian cvs, Misr-1, Misr-2, Misr-3, Giza-168, Giza-171, Sids-13, Sids-14 and ten CIMMYT genotypes, Lee, Otane, Pavon-F-76, Opata-85, Tatara, Janz, Gatcher, Kenya-Sunbird, Exchange, Quaiu-1 appear to have consistently effective partial resistance to both diseases and may therefore be of value in breeding for durable resistance to powdery mildew and leaf rust under Egyptian field conditions. Although partial resistance has proved to be durable, the concept of durability contains two elements. One is that the resistance should remain effective for a long time, and the other is that it should be effective in widespread use in an environment favorable to the disease (Johnson 1984). Consequently, no experimental method can provide as strong a test of durability as growing cultivars in an agricultural situation (Yu et al., 2001).

A strong inverse correlation observed between seedling partial resistance traits (IP, LP) and adult plant partial resistance traits (ADI, ACl, $r$-AUDPC) indicates that these seedling traits contribute to curbing the process of epidemic development in field conditions. Although, values of IP and LP may be strongly influenced by minor differences in pathogen virulence early in the respective year when virulence is low (Shaner and Finney 1977). The rapid development of new leaves at the time of stem elongation also frequently results in a decrease in the percentage of diseased leaf area, causing disease progress curves often to lie far from the theoretical sigmoidal curves (Knudsen et al., 1986). However, this inverse correlation demonstrates facilitating the evaluation of partial resistance levels by IP and LP. A strong correlation observed between ADI, ACI and $r$ AUDPC implies that wheat breeders may be able to assess their lines by a single scoring at an appropriate time (Yu et al., 2001). In the field, inoculation increased disease severity compared with the levels on susceptible check genotypes, but the correlation between seedling partial resistance traits (IP, LP) and adult partial resistance traits (ADI, ACl, $r$-AUDPC) was very high. This indicates, on one hand, that the inoculum used was representative of the local pathogen virulence spectrum, and on the other hand, that breeders may be able to select resistant cultivars and lines without needing to inoculate trials, provided that check susceptible disease severity reaches a sufficiently high level (Yu et al., 2001).

In the wheat mildew and rust pathosystem, cultivars characterized by a susceptible reaction at the seedling stage and a resistant reaction in the adult plant stage are described to possess specific adult plant resistance which is controlled by major genes. Cultivars are susceptible as seedlings but relatively resistant as adult plants are described to possess adult plant partial resistance which is controlled by minor non-race-specific resistance genes, some behave oppositely and others correspond closely in seedling and adult stages (Bennett 1981, Das et al., 1993). In the present study, it is possible that cultivars with seedling and adult plant partial resistance, have effective, non-race-specific resistance genes, rather than specific resistance. These two possibilities could be distinguished with these data based on pedigree information (http://wheatpedigree.net). Adult plant resistance is polygenic and at least 2-3 controlling genes remain successful for a longer time (Dehghani and Moghaddam 2004). Many major and/or minor powdery mildew $(P m)$ and leaf rust ( $L r$ ) resistance genes have been previously reported in wheat cultivars introduced from CIMMYT tested in the current study. For instance, Otane (locality: New Zealand) (Lr1, Lr10, Lr20, Lr34/Pm38) (Dakouri et al., 2013, McIntosh et al., 2008) Jupateco-73-R (Lr12, Lr14a, Lr17, Lr27, Lr31, Lr34/Pm38) (Singh 1992; McIntosh et al., 2008), Pavon-F-76 (Lr1, Lr10, Lr13, Lr14a, Lr22a, Lr27, Lr46/Pm39) (Hussain et al., 1988; Singh and Rajaran 1991, Singh 1997; Rizvi and Buchenau 1994; Mclntosh et al., 2008), Opata-85 (Lr10, Lr13, Lr14b, Lr27, Lr30, Lr31, Lr34/Pm38) (Singh and Rajaran 1991; Kolmer et al., 2008; Mclntosh et al., 2008), Tatara (locality: Pakistan) Lr10, Lr13, Lr27, Lr31 Lr26/Pm8) (Hussain 2009; Mustafa et al. 2013), Hussar (locality: Great Britain) (Pm2, Pm4b, Lr37, Lr26/Pm8) (Borum 2001; Blaszczyk et al. 2004; Hysing et al. 2006), Amigo (locality: USA) (Pm17, Lr24, Lr26) (Zeller et al., 1993), Thew (locality: Australia) (Lr20/Pm1) (Browder 1972; Stepien et al., 2004), Kiskadee-1, Chewink-1 (Lr19), Transec (locality: USA) Lr1, Lr2a, Lr2c, Lr25/Pm7 (Lowry et al., 1984; Friebe et al., 1996). In Egypt, numerous $P m$ and $L r$ resistance genes have been identified as a host material of Egyptian wheat cultivars. For instance, Lr9 (Sids-12), Lr10 (Misr1), Lr19 (Misr-1, Misr-2) (Abou-Elseoud et al., 2014; Awaad and El-Naggar 2021), Lr34 (Sakha-94, Sids-13) (Fahmi et al. 2015), Pm13, Pm36, Pm37 (Beniswef-1, Beniswef-3, Beniswef-4, Sohag-3 (Mohamed and Elkot 2020), Lr29, Lr46, Lr47 (Giza-171, Sids-14) (Omara and Abdelaal 2017). It would seem clear that the pleiotropic adult plant partial resistance genes, including Lr34/Pm38 and Lr46/Pm39 were introduced into the Egyptian germplasm through local breeding programmes from Mexican germplasm which provide us annually by CIMMYT, Mexico. Frontana is one of the first two cultivars released by Norman Borlaug obtained by selection from crosses made by McFadden (Borlaug et al., 1949). It was also observed that Lr34/Pm38 present in cv Sakha-94 derived from OPATA-85/RAYON-89//KAUZ,MEX likely came from Mexican germplasm OPATA-85. Likewise, $L$ r46/Pm39 present in Egyptian cultivars also appears to be coming from Mexican germplasm, for instance, cv Pastor in the pedigree of cv Misr-1, Frontana in crosses of the pedigree of cultivars Sakha-93, Giza-168, Gemmeiza-9, Sids-13 as well as Pavon-F-76 present in crosses of Shandweel-1. The presence of Lr34/Pm38 and Lr46/Pm39 in many newly released CIMMYT genotypes was also attributed to cv Frontana (Huerta-Espino et al., 2020). It is worth noting that the pedigree indicates the presence of many other genes with major or minor effectors in the cultivars that may support resistance.

\section{CONCLUSION}

Screening findings of the Egyptian wheat cultivars and wheat genotypes introduced from CIMMYT implied that they have partial resistance to powdery mildew and leaf rust as seedlings and adult plants which should be considered in breeding programmes for durable resistance to both diseases, possessing effective $P m$ and $L r$ resistance genes. 


\section{CONFLICT OF INTERESTS}

The authors declare that they have no conflict of interests.

\section{REFERENCES}

Abdel-Hak, T.M., EL-Sherif, N.A., Bassiouny, A.A., Shafik I.I., \& EL- Dauadi, Y.H. (1980). Control of wheat leaf rust by systemic fungicides. In Proceedings of the Fifth European and Mediterranean Cereal Rusts Conference, Bari, Italy (p. 255-266).

Abdelrhim, A., Abd-Alla, H.M., Abdou, E.S., Ismail, M.E., \& Cowger, C. (2018). Virulence of Egyptian Blumeria graminis f. sp. tritici population and response of Egyptian wheat cultivars. Plant Disease, 102(2), 391-397.

Asad, S., Fayyaz, M., Munir, A., \& Rattu, A.R. (2014). Screening of wheat commercial varieties for resistance against powdery mildew (Blumeria graminis f. sp. tritici) at Kaghan Valley, Pakistan. Pakistan Journal of Phytopathology, 26(1), 07-13.

Ashmawy, M., El-Orabey, W.M., Abu Aly, A.A., \& Shahin, A.A. (2014). Losses in grain yield of some wheat cultivars infected with powdery mildew. Egyptian Journal of Phytopathology, 42(1), 71-82.

Awaad, H.A., \& El-Naggar, D.R. (2021). Developing Rust Resistance of Wheat Genotypes Under Egyptian Conditions. Mitigating Environmental Stresses for Agricultural Sustainability in Egypt, 311.

Bennett, F.G. (1981). The expression of resistance to powdery mildew infection in winter wheat cultivars. II. Adult plant resistance. Annals of Applied Biology, 98(2), 305-317.

Bennett, F.G. (1984). Resistance to powdery mildew in wheat: a review of its use in agriculture and breeding programmes. Plant Pathology, 33(3), 279-300.

Błaszczyk, L., Goyeau, H., Huang, X. Q., Röder, M., Stepień, L., \& Chełkowski, J. (2004). Identifying leaf rust resistance genes and mapping gene Lr37 on the microsatellite map of wheat. Cellular \& Molecular Biology Letters, 9(4B), 869-878.

Borlaug, N.E., Rupert, J.A., \& Harrar, J.G. (1949). Nuevos trigos para México. Oficina de estudios especiales Secretaria de Agricultura y Ganadería Vol. No. 5 (México: D. F. Folleto de divulgación), 29 p.

Borum, F. (2001). Danish wheat pool. In The World Wheat Book. A history of wheat breeding. Ed. A.P. Bonjean, W.J. Angus. Londres-Paris-New York. (p. 243-256).

Browder, L.E. (1972). A multi-culture inoculation system for study of host-parasite relationships. Plant Disease Reporter, 56, 847-849.

Browning, J.A., \& Frey, K. J. (1969). Multiline cultivars as a means of disease control. Annual Review Phytopathology, 7, 355382.

Dakouri, A., McCallum, B.D., Radovanovic, N., \& Cloutier, S. (2013). Molecular and phenotypic characterization of seedling and adult plant leaf rust resistance in a world wheat collection. Molecular Breeding, 32, 663-677.

Das, M.K., Rajaram, S., Kronstad, W.E., Mundt, C.C., \& Singh, R.P. (1993). Associations and genetics of three components of slow rusting in leaf rust of wheat. Euphytica, 68, 99-109. https://doi.org/10.1007/BF00024159

Dehghani, H., \& Moghaddam, M. (2004). Genetic analysis of the latent period of stripe rust in wheat seedlings. Journal of Phytopathology, 152, 325-330. https://doi.org/10.1111/j.1439-0434.2004.00848.x

Draz, I.S., Abou-Elseoud, M.S., Kamara, A.M., Alaa-Eldein, O.A., \& El-Bebany, A.F. (2015). Screening of wheat genotypes for leaf rust resistance along with grain yield. Annals of Agricultural Sciences, 60, 29-39. http://dx.doi.org/10.1016/j.aoas.2015.01.001

Draz, I.S., Elkot, A.F., \& Abdelrhim, A.S. (2021). Allelism and resistance loci of powdery mildew and leaf rust in Egyptian hexaploid bread wheat. Cereal Research Communications, In Press.

Draz, I.S., Esmail S.M., Abou-Zeid M.A.E.-H., \& Essa T.A.E.-M. (2019). Powdery mildew susceptibility of spring wheat cultivars as a major constraint on grain yield. Annals of Agricultural Sciences, 64 (1), 39-45. https://doi.org/10.1016/j.aoas.2019.05.007

El-Daoudi, Y.H., Shenoda, Ikhals, S., Bassiouni, A.A., Sherif, S.E., \& Khalifa, M.M. (1987). Genes conditioning resistance to wheat leaf and stem rust in Egypt. In Proceedings of the Fifth Egyptian Phytopatholgical Society, Giza, Egypt (p. 387404).

El-Shamy, M.M., Sallam, M.E.A., \& Awad, H.M.F. (2012). Powdery mildew infection on some Egyptian bread wheat cultivars in relation to environmental conditions. Journal of Plant Protection \& Pathology, 3, 363-372.

Fahmi, A.I., El-Shehawi, A.M., \& El-Orabey W.M. (2015). Leaf rust resistance and molecular identification of Lr34 gene in Egyptian wheat. Journal of Microbial \& Biochemical Technology, 7(6), 338-343. DOI: 10.4172/1948-5948.1000236

Friebe, B., Jiang, J., Raupp, W.J., McIntosh, R. A., \& Gill, B.S. (1996). Characterization of wheat-alien translocations conferring resistance to diseases and pests: current status. Euphytica, 91(1), 59-87.

Germán, S., Barcellos, A., Chaves, M., Kohli, M., Campos, P., \& de Viedma, L. (2007). The situation of common wheat rusts in the Southern Cone of America and perspectives for control. Australian Journal of Agricultural Research, 58(6), 620-630. https://doi.org/10.1071/AR06149

Griffey, C.A., Das, M.K. \& Stromberg, E.L. (1993). Effectiveness of adult-plant resistance in reducing grain yield loss to powdery mildew in winter wheat. Plant Disease., 77, 618-622.

Herrera-Foessel, S.A., Singh, R.P., Huerta-Espino, J., Crossa, J., Yuen, J., \& Djurle, A. (2006). Effect of leaf rust on grain yield and yield traits of durum wheats with race-specific and slow-rusting resistance to leaf rust. Plant Disease, 90, 10651072.

Hua, W., Liu, Z., Zhu, J., Xie, C., Yang, T., Zhou, Y., Duan, X., Sun, Q., \& Liu, Z. (2009). Identification and genetic mapping of Pm42, a new recessive wheat powdery mildew resistance gene derived from wild emmer (Triticum turgidum var. dicoccoides). Theological Applied Genetics, 119, 223-230. 
Huerta-Espino, J., Singh, R., Crespo-Herrera, L.A., Villaseñor-Mir, H.E., Rodriguez-Garcia, M.F., Dreisigacker, S., BarcenasSantana, D., \& Lagudah, E. (2020). Adult plant slow rusting genes confer high levels of resistance to rusts in bread wheat cultivars from Mexico. Frontiers in Plant Science, 11, 824. doi: 10.3389/fpls.2020.00824

Huerta-Espino, J., Singh, R.P., German, S., McCallum, B.D., Park, R.F., Chen, W.Q., Bhardwaj, S.C., \& Goyeau, H. (2011). Global status of wheat leaf rust caused by Puccinia triticina. Euphytica, 179, 143-160.

Hussain, F. (2009). Postulation of rust resistance genes in wheat germplasm and improvement of rust resistance in Inqilab91 through marker assisted selection. The University of Sydney Plant Breeding Institute

Hussain, M., Hakro, A.A., Aslam, M., \& Gordon-Werner, E. (1988). Postulated genes for rust resistance in Pakistani wheats. In Proceedings of the seventh European and Mediterranean Cereal Rusts Conference, Vienna, Austria. (p. 33-35).

Hysing, S.-C., Singh, R.P, Huerta-Espino, J., Merker, A., Liljeroth, E. \& Diaz, O. (2006). Leaf rust (Puccinia triticina) resistance in wheat (Triticum aestivum) cultivars grown in Northern Europe 1992-2002. Hereditas, 143, 1-14. https://doi.org/10.1111/j.2005.0018-0661.01917.x

Johnson, R. (1984). A critical analysis of durable resistance. Annual Review of Phytopathology, 22(1), 309-330.

Jones, I.T., \& Davies, I.J.E.R. (1985). Partial resistance to Erysiphe graminis f. sp. hordei in old European barley varieties. Euphytica, 34, 499-507.

Knudsen, J.C.N., Dalsgaard, H.H., \& Jorgensen, J.H. (1986). Field assessment of partial resistance to powdery mildew in spring barley. Euphytica, 35, 233-243.

Kolmer, J.A., Long, D.L., \& Hughes, M.E. (2007). Physiological specialization of Puccinia triticina on wheat in the United States in 2005. Plant Disease, 91 (8), 979-984.

Kolmer, J.A., Singh, R.P., Garvin, D.F., Viccars, L., William, H.M., Huerta-Espino, J., Ogbonnaya, F.C., Raman, H., Orford, S., Bariana, H.S. \& Lagudah, E.S. (2008). Analysis of the Lr34/Yr18 rust resistance region in wheat germplasm. Crop Science, 48(5), 1841-1852. https://doi.org/10.2135/cropsci2007.08.0474

Kranz, J. (1983). Epidemiological parameters of plant resistance. In Durable Resistance in Crops, p. 141-161. Springer, Boston, MA.

Leath, S., \& Bowen, K.L. (1989). Effects of powdery mildew, triadimenol seed treatment, and triadimefon foliar sprays on yield of winter wheat in North Carolina. Phytopathology, 79, 152-155.

Lesovoi, M.P., Shelekhova, L.M., Panteleev, V.K., Kondratyuk, O.K., \& Tesel'ko, V.L. (1981). The harmfulness of brown leaf rust of wheat. Zakhist Roslin, 28, 56-59.

Li, H., Wang, X., Song, F., Wu, C., Wu, X., Zhang, N., Zhon, Y., \& Zhang, X. (2011). Response to powdery mildew and detection of resistance genes in wheat cultivars from China. Acta Agronomica Sinica, 37(6), 943-954.

Lowry, J.R., Sammons, D.J., Baenziger, P.S., \& Moseman, J.G. (1984). Identification and characterization of the gene conditioning powdery mildew resistance in Amigo wheat. Crop Science, 24 (1), 129-132.

McIntosh R.A., Yamazaki Y., Dubcovsky J. et al. (2008). Catalogue of gene symbols for wheat. In Proceedings of the $11^{\text {th }}$ International Wheat Genetics Symposium, 24-29 August 2008, Brisbane, Australia

Mohamed M.E., \& Elkot A.F. (2020). Molecular identification of some powdery mildew resistance genes in ten Egyptian durum wheat cultivars. Journal of Plant Protection \& Pathology, 11 (4), 205-209.

Mustafa, G., Alam, M.M., Khan, S.U. Naveed, M., \& Mumtaz, A.S. (2013). Leaf rust resistance in semi dwarf wheat cultivars. a conspectus of post green revolution period in Pakistan. Pak. J. Bot., 45 (SI), 415-422.

Mutari, B., Udupa, S.M. Mavindidze, P., \& Mutengwa, C.S. (2018). Detection of rust resistance in selected Zimbabwean and ICARDA bread wheat (Triticum aestivum) germplasm using conventional and molecular techniques. South African Journal of Plant and Soil, 35(2), 101-110, DOI: 10.1080/02571862.2017.1336260

Nazim, M.S., El-Shehidi, A.A., Abdou, Y.A., \& El-Daoudi, Y.H. (1983). Yield loss caused by leaf rust on four wheat cultivars under epiphytotic levels. In Proceedings of the fourth Conference of Microbiology, Cairo, 1983, (p. 17- 27).

Ohm, H.W., \& Shaner, G.E. (1976). Three components of slow leaf- rusting at different growth stages in wheat. Phytopathology 66, 1356-1360.

Omara, R.I., \& Abdelaal, K.A.A. (2017). Molecular and genetic analysis of leaf rust resistance genes in two new Egyptian wheat cultivars. Egyptian Journal of Phytopathology, 45(2), 33-52.

Pandey, H.N., Menon, T.C.M., \& Rao, M.V. (1989). A simple formula for calculating area under disease progress curve. RACHIS, $8(2), 38-39$.

Parlevliet, J.E. (1975). Partial resistance of barley to leaf rust, Puccinia hordei. I. Effect of cultivar and development stage on latent period. Euphytica, 24, 21-27.

Parlevliet, J.E., \& van Ommeren A. (1975). Partial resistance of barley to leaf rust, Puccinia hordei. II. Relationship between field trials, micro plot tests and latent period. Euphytica, 24, 293-303.

Pathan, A.K., \& Park, R.F. (2006). Evaluation of seedling and adult plant resistance to leaf rust in European wheat cultivars. Euphytica, 149, 327-342.

Pearson, E.S., \& Hartley, H.O. (1970). Biometrika Tables for Statisticians, $3^{\text {rd }}$ ed. vol. I Cambridge University Press.

Peterson, R.F., Campbell, A.B., \& Hannah, A.E. (1948). A diagrammatic scale for estimating rust intensity on leaves and stems of cereals. Canadian journal of research, 26(5), 496-500.

Rizvi, S.S.A., \& Buchenau, G.W. (1994). Tentative identification and verification of genes for leaf rust resistance in wheat cultivar of South Dakota. Plant Disease, 78 (7): 674-679.

Roelfs, A.P., Singh, R.P., \& Saari, E.E. (1992). Rust Diseases of Wheat: Concepts and Methods of Disease Management. CIMMYT, Mexico, D.F. 
Saari, E. E., \& Wilcoxson, R. D. (1974). Plant disease situation of high-yielding dwarf wheats in Asia and Africa. Annual Review of Phytopathology, 12(1), 49-68.

Saari, E.E., \& Prescott, J.M. (1975). A scale for appraising the foliar intensity of wheat diseases. Plant Disease Reporter, 59, 377-380.

Saari, E.E., \& Prescott, J.M. (1985). World distribution in relation to economic losses. In Roelfs, A.P., Bushnell, W.R. (Eds.), The Cereal Rusts, Academic Press, vol. 2. Orlando, FL, (p. 259-298).

Shaner, G. (1973). Evaluation of slow-mildewing resistance of Knox wheat in the field. Phytopathology, 63, 867-872.

Shaner, G., \& Finney, R.E. (1977). The effect of nitrogen fertilization on the expression of slow-mildewing resistance in Knox wheat. Phytopathology, 67, 1051-1056.

Sharma, R.C., \& Duveiller, E. (2007). Advancement toward new spot blotch resistant wheats in South Asia. Crop Science, 47, 961-968.

Shi, Q.M., Zhang, X.X., \& Duan, X.Y. (1987). Identification of isolates of Blumeria graminis f. sp. tritici. Sci. Agric. Sin. 20(5), 6470.

Singh, R. P., \& Rajaran, S. (1991). Resistance to Puccinia recondita f. sp. tritici in 50 Mexican bread wheat cultivars. Crop Science, 31(6), 1472-1479.

Singh, R.P. (1992). Association between gene Lr34 for leaf rust resistance and leaf tip necrosis in wheat. Crop Science, 32 (4), 874-878.

Singh, R.P. (1997). Utilization of race-specific and durable resistance to rusts in wheat improvement. In Proceedings of Conference of Approaches to improving disease resistance to meet future needs: Airborne pathogens of wheat and barley. 11-13 Nov. 1997, Praha, Czech Rep. 1997. (p. 7-14).

Steel, R.G.D., \& Torrie, J.H. (1980). Principles and Procedures of Statistics, $2^{\text {nd }}$ ed. Mc Graw Hill Book Company, New York.

Stepien, L.., Chelkowski, J., Wenzel, G. Mohler, V. (2004). Combined use of linked markers for genotyping the Pm1 locus in common wheat. Cell. Mol. Biol. Lett. 9 (4), 819-827.

Tervet, l., \& Cassell, R.C. (1951). The use of cyclone separation in race identification of cereal rusts. Phytopathology, 41, 282285.

van Silfhout, C.H., \& Gerechter-Amitai, Z.K. (1989). A comparative study of resistance to powdery mildew in wild emmer wheat in the seedling and adult plant stage. Netherlands Journal of Plant Pathology, 94, 177-184. https://doi.org/10.1007/BF02006543

Vanderplank, J. E. (1968). Disease Resistance in Plants. Academic Press, New York.

Wolfe, M.S. (1985). The current status and prospects of multiline cultivars and variety mixtures for disease resistance. Annual Review of Phytopathology, 23, 451-466.

Yu, D.Z., Yang, X.J., Yang, L.J., Jeger, M.J. \& Brown, J.K.M. (2001). Assessment of partial resistance to powdery mildew in Chinese wheat varieties. Plant Breeding, 120, 279-284. https://doi.org/10.1046/j.1439-0523.2001.00592.x

Zadoks, J.C., Chang, T.T., \& Konzak, C.F. (1974). A decimal code for the growth stage of cereals. Weed Research, 14, 415-421. Zeller, F.J., Lutz J., \& Stephan, U. (1993). Chromosome location of genes for resistance to powdery mildew in common wheat (Triticum aestivum L.). 1. Mlk and other alleles at the Pm3 locus. Euphytica, 68 (3), 223-229.

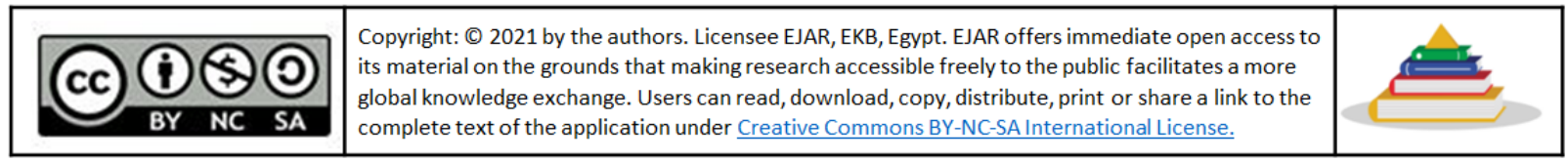




\title{
المقاومة الجزئية للبياض الدقيقي وصدأ أوراق القمح في الطرز الوراثية المصرية والسيميت
}

\author{
ابراهيم صببي دراز1* ، ثناء حمد عبد الكريم²

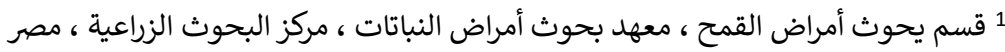

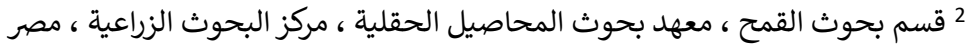

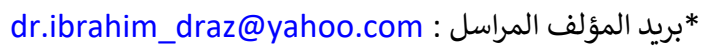

\section{الملخص العربى}

يعتبر البياض الدقيقي الناجم عن Blumeria graminis f. sp. tritici وصدأ الأوراق الناجم عن Puccinia triticina من أهم الأمراض المنتشرة

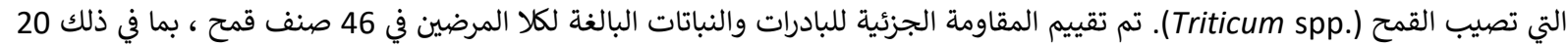

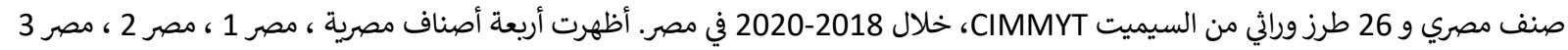

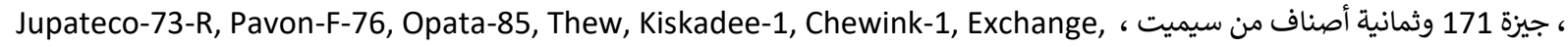

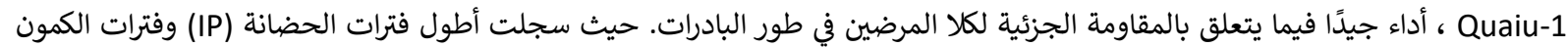

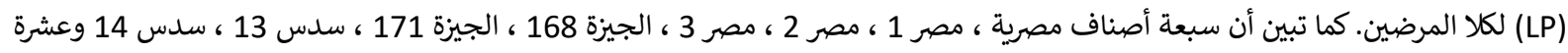

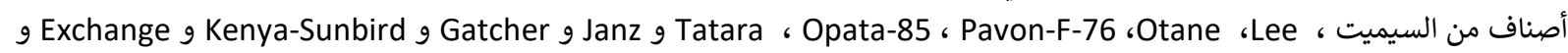
الاصابة ل لديaiu-1

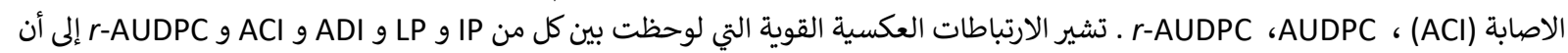

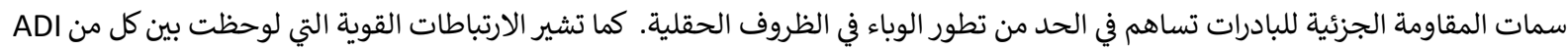

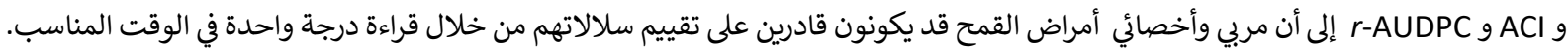

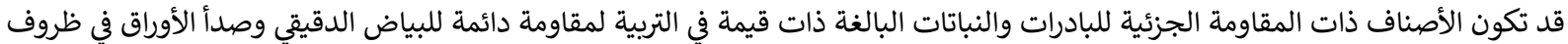
الحقل المصرية. 